\title{
IS THE TRANS-PACIFIC PARTNERSHIP'S INVESTMENT CHAPTER THE NEW "GOLD STANDARD"?
}

\author{
José E Alvarez*
}

\begin{abstract}
The Trans-Pacific Partnership's Investment Chapter, and particularly its inclusion of investor-state dispute settlement (ISDS), has been the focus of considerable criticism both in the United States and New Zealand. Despite huge differences between these two potential TPP partners, the anticipated economic and political benefits offered by the pact - but also the threats to democracy posed - have been expressed in similar ways by distinct stakeholders in both countries. This essay describes how this chapter is the culmination of reforms to United States investment protection treaties that began with the investment chapter of the North American Free Trade Agreement in 1994 and that are now evident in the latest United States Model Bilateral Investment Treaty (of 2012). The TPP's Investment Chapter borrows heavily from prior United States efforts to narrow investor rights (as with respect to fair and equitable treatment), expand sovereign policy space, and incorporate certain rule of law reforms. For its critics, the pact falls far short of achieving a new "gold standard" precisely because it merely reforms - but does not abandon - ISDS for its enforcement.

Editor's note: The text of this article was originally accepted for publication in March 2016. Recent statements by President-elect Donald Trump indicate that the United States will likely withdraw from further participation in the Trans Pacific Partnership and refrain from ratifying the agreed text. Without the United States' ratification, the agreement will not come into force. Despite this apparent ending to the Trans Pacific Partnership, the editors consider that Professor Alvarez's article remains an extremely useful analysis of investment provisions that may well serve as a model for the negotiation of such provisions in other mega-regional trade agreements in the future.
\end{abstract}

* Herbert and Rose Rubin Professor of International Law, New York University School of Law. This is an expanded version of a speech originally delivered at the Victoria University of Wellington, New Zealand on 8 December 2015. 
The United States presidential candidate Hillary Clinton has answered the question posed by my title in two different ways. A few years ago, as United States Secretary of State, she argued that the Trans-Pacific Partnership (TPP) was the new "gold standard" in Free Trade Agreements (FTAs). ${ }^{1}$ More recently, as a presidential candidate attentive to United States Democratic Party primary voters, she has said that its final text reveals that it simply does not make United States workers better off and that she opposes its ratification. The agreement, she now says, gives United States workers something less than gold. ${ }^{2}$ It could be that Secretary Clinton has been talking about the TPP as a whole and not its investment chapter. But that is doubtful insofar as the investment chapter is far too integral to this agreement and, more importantly, to debates about the merits of the TPP. It is probably fair to say that Secretary Clinton has changed her mind about the TPP's investment chapter. This contribution attempts to put her quandary in context.

Some time ago, trade and investment regimes were distinct economically and certainly legally. The regulation of trade in goods was governed by the World Trade Organization (WTO) and stateto-state dispute settlement, and trans-national capital flows by some 3,200 bilateral and regional international investment agreements. These agreements generally provided foreign investors protected by them with direct access to suing their host states in investor-state dispute settlements governed by the World Bank's International Centre for Settlement of Investment Disputes (ICSID) rules or the United Nations Commission on International Trade Law (UNCITRAL). Over time this changed. Increasingly - and especially as the WTO's capacity for generating new liberalisation commitments has stagnated - much of the world, including to some extent New Zealand, has turned to FTAs that combine trade and investment liberalisation even while keeping the forms of dispute settlement for each distinct. Much of the reason responds to changes in the world economy, and helps to explain why the TPP is a "mega-agreement" in both geographic and substantive scope.

The TPP's investment chapter (itself over 50 pages long, including nine annexes) is only one chapter (of 30). It is only a part of a treaty whose mega ambitions are as vast as its economic scale. ${ }^{3}$ According to the Office of the United States Trade Representative (USTR), the TPP will provide Americans a fair shot at the world's fastest-growing region, the place where half to two-thirds of world trade occurs. ${ }^{4}$ By reducing tariffs, replacing "red tape with the red carpet", enhancing secure payment systems, requiring state-owned enterprises to compete fairly with United States businesses, keeping the internet "open and free", United States businesses - including small and medium sized

1 See Hillary Rodham Clinton, United States Secretary of State "Remarks at Techport Australia" (Adelaide, 15 November 2012).

2 Lauren Carroll "What Hillary Clinton really said about TPP and the 'gold standard'" (13 October 2015) Politifact <www.politifact.com>.

3 "The Trans-Pacific Partnership" Office of the United States Trade Representative <www.ustr.gov> [TPP]

4 "The Trans-Pacific Partnership: Overall US Benefits" Office of the United States Trade Representative <www.ustr.gov>. 
ones - will be better able to set up shop, make things, and sell them to what will be (by 2030) an Asian middle class of some 3.2 billion. ${ }^{5}$ New Zealand's Ministry of Foreign Affairs and Trade (MFAT) is only a tad less effusive: the TPP will safeguard New Zealand's longer-term trading interests, enables wider regional economic integration, levels the playing field among five of New Zealand's top 10 trading partners, achieves greater access to the United States market for the country's services and increases the prospects for United States tourism and investment, while doing much the same with respect to TPP partners (Japan, Peru, Canada and Mexico) with which New Zealand did not previously have an FTA. ${ }^{6}$

The TPP's mega scope covers market access in trade in goods, customs administration, sanitary and phytosanitary measures, financial services, intellectual property, labour and environment, and much else. Its chapter 25 , which pursues the goal of regulatory convergence, will provide grist for administrative lawyers for years to come to the extent it shifts regulatory decision-making to global institutions; that chapter seeks to reduce barriers to integrating rules on such matters as the marketing of certain food stuffs which now hamper trade simply because they differ from jurisdiction to jurisdiction. ${ }^{7}$ That section of the treaty, along with much else including its investment chapter, is responsive to the emergence of an increasingly integrated international production system: corporate networks of foreign and domestic firms that specialise in the production of various parts and components eventually assembled in locations around the world. ${ }^{8}$ This is a system of wealth-generation based on the sale of products of mixed national parentage and increasingly reliant on the digital economy, along with world-wide consumer demands for cheap products. The TPP corresponds to a market where corporate nationality, as well as distinctions between host and home countries of foreign investors, lose their sharpness. These "global value chains" are often regionally centred, as is suggested by the TPP's focus on so-called "Asian value chains" and include both equity (mergers and acquisitions and greenfield investments) and non-equity arrangements (contracts). ${ }^{9}$ These transactions combine tangible and intangible assets (such as research and development (R\&D) or brand names). The TPP responds in substantial part to the needs expressed by these value chains - where the role of corporate headquarters is more likely to be that of coordinating and deciding where various production activities take place.

5 "The Trans-Pacific Partnership: Overall US Benefits", above n 4.

6 New Zealand Ministry of Foreign Affairs and Trade Trans-Pacific Partnership National Interest Analysis (25 January 2016)

7 See generally Richard B Stewart "State Regulatory Capacity and Administrative Law and Governance Under Globalization" (forthcoming, on file with author).

8 See Karl Sauvant The Evolving International Investment Law and Policy Regime: The Way Forward (E15 Initiative, Geneva, January 2016).

9 Sauvant, above $\mathrm{n} 8$. 
The TPP is, from this perspective, an agreement to reduce the costs of firms that engage in cross-border transactions involving both trade in goods and cross-border capital flows. As one knowledgeable observer put it: ${ }^{10}$

As natural market imperfections continue to fall in the digital economy (frictionless, virtual trade), the barriers to trade and foreign direct investment (FDI) flows generated by government policies become more visible and important.

The TPP seeks to harmonise regulation on everything from investment to customs, e-commerce to pharmaceuticals, while setting standards that supposedly will avoid races to the bottom for labour and the environment. This is not to suggest that the TPP is entirely about global supply chains and the goods these produce; some support the treaty - including many in New Zealand - principally because it is likely to expand the markets for old-fashioned New Zealand exports. ${ }^{11}$

Apart from those economic drivers, the TPP also responds to geopolitics. For the current New Zealand government, it signals the country's leadership in the Asian region and situates the country as a potential conduit for reaching out to China, with which New Zealand has a FTA agreement incorporating many of the same investment guarantees, along with the same access to investor-state dispute settlement (ISDS) as exists in the TPP. ${ }^{12}$ The TPP also has the potential to facilitate the path towards an eventual New Zealand-European Union FTA. ${ }^{13}$ For the Obama Administration, the TPP, although originally proposed during the Bush Administration, concretises Obama's "tilt toward Asia" while simultaneously enabling leverage to convince Europe to conclude the Trans-Atlantic Partnership (TTIP) between the European Union and the United States. This also puts pressure on China to join the global marketplace on the basis of reciprocity, and provides a backup plan for advancing trade and investment liberalisation should either the TTIP or the United States' other overtures to China (such as ongoing negotiations for a United States-China bilateral investment treaty) fail. Not surprisingly, Secretary Clinton once called the two mega-regionals, the TPP and the TTIP, an "economic NATO". ${ }^{14}$ To the United States, the TPP's goal - to spread and deepen the

10 Lorraine Eden Multinationals and Foreign Investment Policies in a Digital World (E15 Initiative, Geneva, January 2015) as cited in Sauvant, above n 8, at 14.

11 See for example David Snell "NZ had most to gain from TPP deal" The New Zealand Herald (online ed, Auckland, 15 October 2015).

12 Ministry of Foreign Affairs and Trade, above n 6.

13 For one account of the economic benefits of that prospective agreement from a New Zealand business perspective see New Zealand International Business Forum "Towards a New Zealand-European Union FTA" (July 2015). For a more geopolitical perspective of the benefits of closer New Zealand-European ties see European Commission "Statement of the Presidents of the European Council and the European Commission and the New Zealand Prime Minister" (press release, 29 October 2015).

14 David Ignatius "A free-trade agreement with Europe?" The Washington Post (online ed, Berlin, 5 December 2012) as cited in Eyal Benvenisti "Democracy Captured: The Mega-Regional Agreements and the Future of Global Public Law" IILJ Working Paper 2016/2 (28 March 2016), at 2. See also Clinton, above n 1. 
capitalist marketplace - advances collective security interests no less than its global counterterrorism efforts. Indeed, the TPP is part of the United States' (and perhaps the world's) neverending war on terror. ${ }^{15}$ The current United States administration, like the ancient empire of Athens which was also driven by concerns for security, material self-interest, and self-confidence to spread its way of life ${ }^{16}$ - sees the TPP as an essential part of "rule of law" efforts to, as Vice President Biden immodestly put it, "help shape the character of the global economy". ${ }^{17}$

The TPP, and particularly its investment chapter, has not been as enthusiastically embraced elsewhere. For some, the TPP is part of the United States' "divide and conquer" global strategy: to engage simultaneously in negotiations that reduce the power of weaker trading partners in order to shape the world in its image. To critics like Eyal Benvenisti, the TPP and TTIP negotiations are part of a broader effort by the world's economic hegemon to encourage fragmentation; a turn to regionalism over reliance on global institutions like the WTO or those of the UN system where United States power is now much diminished. ${ }^{18}$ As he sees it, the two ongoing mega-regional negotiations pose a direct challenge to the horizontal equality of states; they pressure those privileged to be included as well as those excluded from each negotiation. ${ }^{19}$ Critics charge that the pressures also extend internally, to alternatively silence or empower distinct interests within states. The secrecy of the negotiations challenge democratic decision-making within the participating states by excluding the voices of civil society, while embracing those commercial interests included in state delegations whose interests are served by these treaties. ${ }^{20}$ Benvenisti and others see ISDS as the perfect tool for perpetuating sovereign inequality by enabling hand-picked arbitrators to displace national judges. To critics, ISDS is the poster child for bypassing the principal mechanism that democracies have for checking the power of their executive branches: namely administrative or constitutional courts. $^{21}$

15 See for example Threats to International Peace and Security Caused by Terrorist Acts SC Res 2249, S/RES/2249 (2015)

16 José E Alvarez "Contemporary International Law: An 'Empire of Law' or the 'Law of Empire'?" (2009) 24 Am U Int'l L Rev 811.

17 Dan Mullaney, United States Chief Negotiator "Opening Remarks by US and EU Chief Negotiators for the Transatlantic Trade and Investment Partnership (T-TIP) Round Nine Press Conference" (press conference, New York, 24 April 2015) as cited in Benvenisti, above n 14, at 3.

18 At 4 .

19 At 4 .

20 At 5 . The lack of transparency with respect to the TPP negotiations has been a recurring complaint. See for example Donna Miles-Mojab "TPPA Debate: We need a Free Trade of Opinions" Stuff.co.nz (online ed, New Zealand, 16 November 2015) <www.stuff.co.nz>; and Jane Kelsey "Govt Spin Won't Stop TPP Facts Emerging" The New Zealand Herald (online ed, New Zealand, 13 October 2015) <www.nzherald.co.nz>.

21 Benvenisti, above n 14, at 6-7. See generally Gus van Harten Investment Treaty Arbitration and Public Law (Oxford University Press, Oxford, 2007). 
The evident differences between the global hegemon, the United States, and New Zealand as potential TPP partners, would suggest that public reactions to the TPP, pro and con, might differ considerably within the two countries. In terms of the relative levels of inward and outgoing capital flows and stock, New Zealand has more in common with fellow TPP partners Chile, Vietnam, and Peru than it does with the United States. ${ }^{22}$ New Zealand's inward FDI stock and capital flows far

22 According to the Treasury's Economic and Financial Overview for 2015, New Zealand was host to $\$ 97.4$ billion of foreign direct investment (FDI), and was a source of $\$ 23.2$ billion of direct investment abroad. This is a measure of FDI stock, not of FDI flows: see Treasury New Zealand Economic and Financial Overview 2015 (2015) at 30. These figures are roughly similar to the 2011 figures, which stood, respectively, at $\$ 93.8$ billion and $\$ 22.9$ billion: see Treasury New Zealand Economic and Financial Overview 2012 (2012) at 33. FDI flows in TPP countries and direct investment abroad by TPP countries are as follows:

\begin{tabular}{|l|l|l|}
\hline Country: & FDI inflows & FDI outflows \\
\hline Brunei & $\$ 568,000,000$ & - \\
\hline Chile & $\$ 22,949,000,000$ & $-\$ 4,000,000 * *$ \\
\hline New Zealand & $\$ 3,391,000,000$ & $\$ 40,660,000$ \\
\hline Singapore & $\$ 67,523,000,000$ & $-\$ 351,000,000 * * *$ \\
\hline Australia & $\$ 51,854,000,000$ & $\$ 52,620,000,000$ \\
\hline Canada & $\$ 53,684,000,000$ & $\$ 113,629,000,000$ \\
\hline Japan & $\$ 2,090,000,000$ & $\$ 16,445,000,000$ \\
\hline Malaysia & $\$ 10,799,000,000$ & $\$ 5,201,000,000$ \\
\hline Mexico & $\$ 22,795,000$ & $\$ 84,000,000$ \\
\hline Peru & $\$ 7,607,000,000$ & $\$ 336,943,000,000$ \\
\hline United States & $\$ 92,397,000,000$ & $\$ 1,150,000,000$ \\
\hline Vietnam & $\$ 9,200,000,000$ & \\
\hline
\end{tabular}

UNCTAD, World Investment Report 2015, Annex at 3.

FDI Stock in and originating from TPP countries is as follows:

\begin{tabular}{|l|c|c|}
\hline Country: & FDI inward stock & FDI outward stock \\
\hline Brunei & $\$ 6,219,000,000$ & $\$ 134,000,000$ \\
\hline Chile & $\$ 207,678,000,000$ & $\$ 89,733,000,000$ \\
\hline New Zealand & $\$ 76,791,000,000$ & $\$ 18,678,000,000$ \\
\hline Singapore & $\$ 912,355,000,000$ & $\$ 576,396,000,000$ \\
\hline Australia & $\$ 564,608,000,000$ & $\$ 443,519,000,000$ \\
\hline Canada & $\$ 631,316,000,000$ & $\$ 714,555,000,000$ \\
\hline
\end{tabular}


outpace its outward flows. ${ }^{23}$ It is more of a host than a home country for FDI. At the same time, New Zealand has been in the past far more amenable than has the United States to supranational scrutiny of its laws through international adjudication. While the United States is not a party to any regional human rights court, the compulsory jurisdiction of the International Court of Justice (ICJ), or the optional protocols of UN human rights treaties enabling the filing of individual human rights complaints to UN human rights treaty bodies, New Zealand has in force a declaration recognising the compulsory jurisdiction of the ICJ and is a party to at least some of the UN human rights optional protocols. ${ }^{24}$ It is not a party to a regional human rights court, one suspects, only because no Asian court exists. One could assume that New Zealanders are far more used to having their local laws "second-guessed" by supranational authorities.

Yet, despite the vast differences in economic power and perhaps ideological inclinations, the concerns about the TPP's investment chapter and especially its recourse to ISDS are strikingly similar in both countries. ${ }^{25}$ In both countries many worry about lessening the scrutiny of those seeking to enter the country as investors. In both places many policymakers would like to be able to distinguish among foreign investors with respect to admission. In both, critics of free trade agreements would like to retain the capacity to block foreign investment with respect to certain sectors or enterprises or with respect to investors of some nationalities. In both places some would

\begin{tabular}{|l|l|l|}
\hline Japan & $\$ 170,615,000,000$ & $\$ 1,193,137,000,000$ \\
\hline Malaysia & $\$ 133,767,000,000$ & $\$ 135,685,000,000$ \\
\hline Mexico & $\$ 337,974,000,000$ & $\$ 131,246,000,000$ \\
\hline Peru & $\$ 79,429,000,000$ & $\$ 4,205,000,000$ \\
\hline United States & $\$ 5,509,884,000,000$ & $\$ 6,318,640,000,000$ \\
\hline Vietnam & $\$ 90,991,000,000$ & $\$ 7,490,000,000$ \\
\hline
\end{tabular}

23 See New Zealand Economic and Financial Overview 2015, above n 22.

24 See "Declarations recognising as Compulsory the Jurisdiction of the International Court of Justice under Article 36, Paragraph 2, of the Statute of the Court" New Zealand Treaties Online <www.treaties.mfat.govt.nz>. New Zealand is a party to the First Optional Protocol of the International Covenant on Civil and Political Rights 999 UNTS 172 (opened for signature 16 December 1966, entered into force 23 March 1976) [ICCPR] and the First Optional Protocol to the Convention Against Torture and Other Cruel, Inhuman Or Degrading Treatment or Punishment 2375 UNTS 237 (opened for signature 18 December 2002, entered into force 22 June 2006).

25 In both countries, anti-TPP advocacy groups express similar concerns. See for example "The Trans-Pacific Partnership" It's Our Future <www.itsourfuture.org.nz〉; and "Trans-Pacific Partnership (TPP): Expanded Corporate Power, Lower Wages, Unsafe Food" Public Citizen <www.citizen.org>. In both countries, probusiness groups have undertaken pro-TPP efforts to counter the criticisms: see for example "TPP Unwrapped" Trade Works <www.tradeworks.org.nz> stressing the benefits to be "growth and jobs". 
like to retain the power to accord entry only as conditioned by certain performance requirements (such as achieving a certain level of exports). ${ }^{26}$

In the United States, fears of the unrestricted entry of foreign investors have, over time, been prompted by waves of Japanese, Middle Eastern, and most recently, Chinese investors. In New Zealand, comparable fears are exacerbated by the relative amount of its much smaller economy that is already in foreign hands. Although the TPP leaves undisturbed New Zealand's Overseas Investment Act 2005 and permits the continued screening of foreign investors according to its terms, critics note that the Treaty seems to preclude the addition of new protected sectors that some would like to see, such as residential housing, at least to the extent that changes to the Act are seen as detrimental to foreign investors. ${ }^{27}$

Both countries have faced criticisms with respect to specific foreign investments, particularly to the extent these are seen as threatening "strategic assets", variously defined. In the United States, controversy emerged in Congress over the contemplated Dubai Ports deal, leading to amendments to the national security screening mechanisms in place. ${ }^{28}$ Most recently, some members of Congress objected to allowing a Chinese enterprise to purchase Smithfield Farms, a leading pork producer. ${ }^{29}$ In New Zealand, comparable doubts were expressed about the wisdom of allowing a Chinese entity, Shanghai Pengxin, to purchase a major farm, Lochinver Station. ${ }^{30}$ In both countries, the prospect of alien land ownership has been especially controversial. In New Zealand, such worries are attributed to a "settlement culture" that goes back to the country's origins and reflects cultural and indigenous rights concerns. ${ }^{31}$ Similarly, the usual United States exception from national treatment, retained in the TPP, that permits states of the United States to maintain restrictions on agricultural land holdings by aliens, also go back to the United States' founding. ${ }^{32}$

26 Compare TPP, above n 3, art 9.9 prohibiting or restricting a variety of performance requirements.

27 See generally Amokura Kawharu "The Admission of Foreign Investment under the TPP and RCEP" (2015) 16 The Journal of World Investment \& Trade 1058.

28 Stephen Heifetz "A Brief History of the Committee on Foreign Investment in the United States" Steptoe \& Johnson <www.steptoe.com>.

29 Shihoko Goto "Why US Angst Over Chinese Buyouts is Warranted" Reuters (online ed, 27 January 2014).

30 See for example Gerald Piddock, Aimee Gulliver and Tao Lin "Shanghai Pengxin Purchase of NZ's Lochinver Station Rejected by Government" Stuff.co.nz (online ed, New Zealand, 17 September 2015).

31 See for example Kawharu, above n 27, at 1078.

32 TPP, above n 3, annex I, sch of the United States (exception for non-conforming measures by United States states). See James R Mason Jr "Pssst, Hey Buddy, Wanna Buy a Country? An Economic and Political Policy Analysis of Federal and State Laws Governing Foreign Ownership of United States Real Estate" (1994) 27 Vand J Transnatl'1 453. 
Critics of investment protection treaties in both places worry about other forms of "regulatory chill". In the United States, fears that the North American Free Trade Agreement (NAFTA) impinges on environmental regulation reached their zenith when California's statewide restrictions on a gasoline additive seen as threatening drinking water were challenged by a Canadian maker of the additive. ${ }^{33}$ In New Zealand, many watched with alarm as Australia's efforts to enforce brown paper packaging for cigarettes faced an ISDS challenge. ${ }^{34}$ In both countries, there are fears that even the rulings of national courts can be challenged or displaced by a single investor claimant - as was suggested by a NAFTA claim brought to challenge a jury verdict rendered by a Mississippi court. ${ }^{35}$ Critics in both countries point to TPP provisions that appear to go "too far" in favour of international arbitration, such as its provision enabling foreign investors to have recourse to arbitration even in the face of clause accepting the jurisdiction of national courts in an investor-state contract. ${ }^{36}$

The concerns about the investment chapter of the TPP expressed in a letter circulated by United States Senator Elizabeth Warren and signed by 100 United States law professors, are similar to those made by some of New Zealand's legal academics. ${ }^{37}$ That letter argued that ISDS violates the rule of law insofar as it grants foreign corporations a special legal privilege that they will use to challenge government policies, actions, or decisions that merely reduce the value of their investments, and force these to be heard in tribunals of private lawyers that enable only foreign companies to sue (but not the state or anyone else hurt by corporate malfeasance). The letter also argued that ISDS is flawed insofar as it lacks the basic protections of national courts such as truly independent adjudicators and a fully-fledged appeals process. ${ }^{38}$ United States critics of ISDS, like their New Zealand counterparts, see it as not only an affront to sovereignty and democratic

33 Methanex Corp v United States (Final Award on Jurisdiction and Merits) (2005) 44 ILM 1345.

34 A plain packaging proposal similar to that enacted in Australia which was the subject of an ISDS challenge has been pending in New Zealand. See Ministry of Health "Plain Packaging" <www.health.govt.nz>. The Philip Morris challenge to Australia's plain packaging law was dismissed on jurisdictional grounds in December 2015 but that ruling remains unavailable as of February 2016: see Daniel Hurst "Australia Wins International Legal Battle with Philip Morris over Plain Packaging" The Guardian (online ed, London, 17 December 2015).

35 See Loewen Group, Inc v United States (Award) ICSID ARB(AF)/98/3, 26 June 2003

36 See for example Amokura Kawharu "TPPA: Chapter 9 on Investment, Trans-Pacific Partnership Agreement" (2015) Trans-Pacific Partnership Agreement New Zealand Expert Paper Series.

37 Compare Letter from Alliance for Justice to Mitch McConnell (United States Senate Majority Leader), Harry Reid (Senate Minority Leader), John Boehner (Speaker of the House of Representatives), Nancy Pelosi (House of Representatives Minority Leader), and Michael Froman (United States Trade Representative Ambassador) regarding investor-state dispute settlement (20 April 2015), to Kelsey, above $n$ 20 and Jane Kelsey "Trade negotiations with EU, just as fraught as TPP" The New Zealand Herald (online ed, New Zealand, 5 November 2015).

38 Alliance for Justice, above n 37. 
governance, but as a tool to weaken the rule of law by removing procedural protections while turning to an unaccountable, unreviewable system of "private justice". 39

These concerns are not limited, of course, to the United States and New Zealand. European critics of ISDS have expressed similar concerns, even in a continent that is no stranger to submitting local laws to the scrutiny of international courts. Indeed, as many as 250,000 people came out in October 2015 on the streets of Berlin to protest the prospective TTIP. ${ }^{40}$ In response to public consultations by the European Commission some 150,000 comments on the TTIP's investment chapter were received; many expressed ire at the prospect that the TTIP might include ISDS. ${ }^{41}$ Whether or not in response, the European Union recently tabled a proposal that would, among other things, replace ISDS in the TTIP with an international investment court with judges appointed for up to 12 years and a process for appeals. ${ }^{42}$ To many Europeans that proposal, not the TPP's oldfashioned reliance on ISDS, constitutes the real gold standard.

To summarise, there are five general complaints against treaties like the TPP and against ISDS:

(1) Such treaties, and ISDS as its enforcement tool, threaten the sovereign right to regulate. Even the threat of an investor claim - such as the tobacco industry's investor-state claims against the plain packaging of cigarettes in a number of jurisdictions ${ }^{43}$ - and, of course, the harsh reality of arbitral awards that may set the losing state back millions of dollars, can prompt regulatory chill.

(2) These agreements are not needed to make rich countries richer. Economists differ on whether concluding a bilateral investment treaty (BIT) or FTA actually increases the amount of FDI such treaty parties receive or that these treaties otherwise contribute positively to GDP. ${ }^{44}$ There is little evidence that, for example, the existence of these

39 See for example Public Citizen NAFTA Chapter 11 Investor-to-State Cases: Bankrupting Democracy Lessons for Fast Track and the Free Trade Area of the Americas (September 2001).

40 "Thousands protest in Berlin against EU-United States trade deal" Al Jazeera (online ed, Qatar, 11 October 2015).

41 European Commission Online Public Consultation on Investment Protection and Investor-to-State Dispute Settlement (ISDS) in the Transatlantic Trade and Investment Partnership Agreement (TTIP) (Brussels, 13 January 2015) [Draft TTIP Text].

42 For the rationales for the European Union proposal see European Commission Investment in TTIP and Beyond - the Path to Reform (Brussels, May 2015). See also the discussion below at 534-536 and n 146155 .

43 See for example Tania Voon and Andrew Mitchell "Time to Quit? Assessing International Investment Claims Against Plain Tobacco Packaging in Australia" (2011) 14 J Intl Econ L 515.

44 For one collection of studies see Karl P Sauvant and Lisa E Sachs The Effect of Treaties on Foreign Direct Investment: Bilateral Investment Treaties, Double Taxation Treaties, and Investment Flows (Oxford University Press, Oxford, 2009). For a more recent update see United Nations Conference on Trade and 
treaties influence the decisions of CEOs on where to invest. ${ }^{45}$ It is said that CEOs go where the consumers or where their inputs are (for example oil or other natural resources); they go where the profits, not treaties, are. To some, entering into a BIT does not only fail to guarantee FDI flows, it can sometimes hinder them. This can happen, for example, if they result in adverse investor-state rulings (as against Argentina) whether or not justified on the merits, which send adverse signals to foreign investors waiting in the wings.

(3) The investment regime does not help less developed countries to develop in a more holistic sense. It is said that even if the enactment of treaty protections for foreign investors does promote the entry of foreign capital (along with more favourable assessments of political risk by credit agencies), this does little to enhance the contribution that foreign capital may make to the host state or to overall improvements in the national rule of law. ${ }^{46}$ One form of this critique reflects a more chastened view of the merits of the ostensible model for economic development encouraged by strongly investor-protective treaties, such as the United States-Argentina BIT and others concluded in the post-Cold War euphoria of the 1990s. ${ }^{47}$ Such treaties are seen as part and parcel of the International Monetary Fund's apparent turn to the trifecta of deregulation, respect for property rights, and divestment of state enterprises - the so called and (much maligned) "Washington Consensus" or its slightly reformed version, the "post Washington Consensus". ${ }^{48}$ A more extreme form of this critique has been expressed by Ecuador's President Rafael Correa, among others. As Correa put it in his 2014 Prebisch lecture, investment treaties are an open and shut case of neocolonialism insofar as they put the needs of capital above those of human beings, displace sovereign concerns with arbitration, ignore the need to exhaust local remedies (unlike, for example, the Inter-American system for human rights), and prevent reforms in favour of the public interest. ${ }^{49}$

Development The Impact of International Investment Agreement on Foreign Direct Investment: An Overview of Empirical Studies 1998-2014 (IIA Issues Note - Working Draft, September 2014).

45 See for example Jason W Yackee "Do Bilateral Investment Treaties Promote Foreign Direct Investment? Some Hints from Alternative Evidence" (22 March 2010) University of Wisconsin Legal Studies Research Paper No 1114.

46 See for example Yackee, above n 45. For a sceptical view of the impact of such treaties on the national rule of law see Tom Ginsburg "International Substitutes for Domestic Institutions: bilateral investment treaties and governance" (2005) 25 Int'l Rev of L \& Econ 107.

47 José E Alvarez "The Evolving BIT" in Ian A Laird and Todd J Weiler (eds) Investment Treaty Arbitration and International Law (Juris Net, May 2010) 1 at 13-14.

48 Alvarez, above n 47.

49 Rafael Correa Delgado, President of Ecuador "Ecuador: Development as a Political Process" (Prebisch Lecture 2014, Geneva, 24 October 2014). 
(4) ISDS violates the rule of law. Ad hoc arbitral tribunals from which there is no full scale appeal to correct errors of law, are said to produce inconsistent, ill-reasoned, and sometimes incoherent arbitral awards that fail to provide the certainty demanded by either investors or states. ${ }^{50}$ ISDS rulings may also be inconsistent with law produced elsewhere (including by UN human rights treaty bodies or regional human rights courts). Critics charge that ISDS case law tends to reproduce partisan and political divides that are replicated through repeated recourse to party-appointed arbitrators many of whom can be identified as either pro-investor or pro-state and not as the truly impartial judges they were intended to be. ${ }^{51}$ To the extent ISDS was intended to de-politicise the investor-state conflicts, that effort, critics charge, has failed. Rule of law critics include my New York University colleague Benedict Kingsbury who, as head of a scholarly movement that describes global forms of administrative law (or GAL), sees ISDS as a form of global governance desperately in need of greater transparency, participation, enhanced reasongiving, and forms of correction or review. ${ }^{52}$ More vehement critics, like Public Citizen's Lori Wallach, contend that ISDS is a rigged or biased forum in favour of capital since its arbitrators, many of whom are arbitrators one day and claimants' lawyers the next, need to keep investor claimants happy to secure repeated business. ${ }^{53}$ Rule of law concerns are also fed by the absence of ethical rules for those involved in these disputes, as well as the perceived inadequacy of the rules that do exist for challenging arbitrators on the basis of conflicts of interest or because of evidence that they are not inclined to hear a claim impartially. ${ }^{54}$ These latter complaints target ICSID's outdated rules requiring those who challenge an arbitrator to prove a "manifest lack of qualities" and which leave decisions on such challenges to the challenged arbitrator's fellow arbitrators. ${ }^{55}$ The combination of an inappropriately demanding standard in order to disqualify an arbitrator and reliance on inappropriate decision-makers to undertake that judgment may explain why such challenges are rarely successful. ${ }^{56}$

50 See for example Alliance for Justice, above n 37.

51 See for example van Harten, above n 21.

52 Benedict Kingsbury and Stephan Schill "Investor-State Arbitration as Governance: Fair and Equitable Treatment, Proportionality, and the Emerging Global Administrative Law" (2 September 2009) New York University School of Law, Public Law Research Paper No 09-46.

53 Lori Wallach and Todd Tucker "Public Interest Analysis of Leaked Trans-Pacific Partnership (TPP) Investment Text" Public Citizen (13 June 2012) <www.citizen.org>.

54 See generally Chiara Giorgetti "Towards a Revised Threshold for Arbitrators' Challenges Under ICSID?" Kluwer Arbitration Blog (3 July 2014) <www.kluwerarbitrationblog.com>.

55 Georgetti, above n 54.

56 Georgetti, above n 54 . 
(5) Regime reform efforts have been inadequate. The increased precision and narrowing of investor rights in some more recent BITs and FTAs have not eliminated the risk that investor-state arbitrators will second guess sovereign decisions taken in the public interest, such as agency decisions with respect to a private investor's involvement in water delivery services, health care delivery or mining. Despite reforms to restore sovereign policy space, states' environmental review procedures, pollution controls or safety standards continue to be challenged under ISDS.

The result is substantial "sovereign backlash" against investment protection treaties like the TPP's investment chapter. The adverse reaction to the investment regime and to its enforcement tool, ISDS, is particularly evident in countries that have been respondents to investor-state complaints that they deem unwarranted, including Argentina (which at least under the government of President Kirchner refused to comply with ISDS awards), and Ecuador and Venezuela (which have sought to terminate BITs and/or exit from the ICSID convention). ${ }^{57}$ Many other countries, including the United States, have reacted with less vehemence - by striving to reform existing model texts for BITs/FTAs and ISDS rather than exiting both. At the same time, other countries, including pairs of less developed countries (LDCs), continue to conclude treaties that are as protective of investors' rights as those negotiated in the 1990s, when countries embraced the market as the only possible alternative with the end of the Cold War. The result is today's "spaghetti soup" of BITs and FTAs of varying complexions - where countries have reacted to opportunities to exercise Albert Hirschman's exit and voice options in very different ways. ${ }^{58}$

Investment regulation - however it is undertaken and whether or not it involves ISDS inevitably involves five sets of competing choices:

(1) Tensions between the goals of global corporate capital versus those of national businesses. The latter will not always be in favour of an open door policy toward foreign investors, particularly to the extent those investors are perceived as getting better than national treatment, including privileged access to international arbitration.

57 See generally Claire Balchin and others (eds) The Backlash Against Investment Arbitration (Kluwer Law International, 2010).

58 See for example United Nations Conference on Trade and Development Recent Trends in IIAS and ISDS (IIA Issues Note No 1, February 2015). See also United Nations Conference on Trade and Development Reform of the IIA Regime: Four Paths of action and a Way Forward (IIA Issues Note No 3, June 2014). On the general concept of exit and voice as applied to the investment regime see Kathryn Gordon and Joachim Pohl "Investment Treaties over Time - Treaty Practice and Interpretation in a Changing World" (2015) OECD Working Papers on International Investment, drawing on the concept originated by Albert O Hirschman Exit, Voice, and Loyalty: Responses to Decline in Firms, Organizations, and States (Harvard University Press, Cambridge (Mass), 1970). 
(2) Tensions between government policies that are needed to encourage or send "positive signals" to foreign investors and those that are thought necessary to protect certain "sensitive" (or "infant" or "strategically significant") domestic enterprises. ${ }^{59}$

(3) Tensions between policies to attract foreign capital versus policies to maximise its domestic benefits once it arrives in the host country. ${ }^{60}$

(4) Tensions between a country's interest as host state to foreign capital flows versus the needs of home countries of investors needing to protect those investors abroad. ${ }^{61}$

(5) Tensions between needs for harmonised transnational regulatory standards versus needs to preserve "policy space" in pursuit of legitimate country-specific public policy objectives. ${ }^{62}$

These tensions or aspects of them may exist irrespective of the type of investment regulation that occurs; that is, irrespective of whether a country turns to investment protection treaties and ISDS. The tensions may be exacerbated by the legal regimes established for protecting foreign property rights, but these regimes do not cause them. Notably, these tensions may emerge with respect to either passive capital flows or foreign direct investment - even though much of the prominent policy debates focus only on the most prominent manifestation, in physical form, of an "alien" presence in a country by way of foreign mergers or acquisitions or greenfield investment. ${ }^{63}$

Countries have generally had a love and hate relationship with FDI. Their reactions have often resembled Woody Allen's character in Annie Hall's memorable reaction to a restaurant: "such

59 See generally Andrew T Guzman "Why LDCs Sign Treaties That Hurt Them: Explaining the Popularity of Bilateral Investment Treaties" (1998) 38 Va JIL 639. For a concrete manifestation of New Zealand's efforts to balance these competing goals, see for example its 38 page schedule of detailed exceptions from many portions of the TPP, including specific guarantees in its investment chapter.

60 Notably, one tool that some countries use to maximize the benefits of incoming FDI, performance requirements, is severely restricted under the TPP: see TPP, above n 3, art 9.9.

61 See generally Alvarez, above n 47. As noted, both New Zealand and the United States are capital exporting as well as capital importing states although not in the same proportion; whereas the United States remains the world's largest recipient of foreign capital as well as its leading capital exporter, New Zealand's incoming FDI vastly eclipses its outgoing capital: see Treasury, above $\mathrm{n} 22$. Of course, a state that avoids all treaty obligations involving investments or investors and chooses to regulate only through domestic law or regulation could avoid making this choice, but given that some 180 countries are party to at least one investment protection agreement such as BIT, that policy option is not commonly available.

62 See generally Lise Johnson, Lisa Sachs and Jeffrey Sachs "Investor-State Dispute Settlement, Public Interest and US Domestic Law" Vale Columbia Center on Sustainable Investment (Policy Paper, May 2015).

63 Although the TPP's definition of covered investment emphasizes that the treaty protects tangible "assets", see TPP, above n 3, art 9.1, many international investment treaties extend their protections to passive forms of investment. Particularly after the Asian economic crisis, there was renewed attention to the risk posed by foreign capital flows not involving FDI, and the possibility of economic harm produced by rapidly changing flows of even passive capital. 
horrible food - and such small portions". ${ }^{64}$ Countries have long sought more FDI but have also long had second thoughts once they received some. There is no mystery about why this is so. The anticipated benefits of foreign enterprises - increased competitiveness, technological spill-overs, job promotion, lower consumer prices, the prospect of greater economic growth and enhanced exports may come in all too small portions. Worse still, these limited benefits may be accompanied by negative externalities, namely threats to the host state's economy, its politics and even its national security. ${ }^{65}$ Even countries that believe in David Ricardo's theory of comparative advantage fear that foreign enterprises will always be looking for other opportunities (lower wages, lower environmental standards) and therefore be able to extract unattractive concessions by threatening to leave; in the interim, they may buy up valuable assets at fire sale prices, put infant local businesses out of business, monopolise certain sectors, import more than they export, or refuse to provide the host state with the anticipated technological or knowledge spill-overs. Incoming FDI generates political worries. These include fears that foreign enterprises - whose economic power may dwarf a small country's GDP - will unduly influence or corrupt politicians, otherwise meddle in local affairs, violate cultural norms, disrespect the environment, or undermine domestic constituencies (such as the power of local labour unions). Incoming foreign enterprises may generate national security concerns, including fears that foreigners will end up controlling or compromising access to technology needed for the national defence. Such security concerns are only exacerbated when FDI comes in the form of state-owned enterprises or sovereign wealth funds. These forms of FDI, it is feared, may advance the goals of their parent states and not necessarily those of the market.

Our love/hate relationship with foreign capital - and the policy tensions it entails - is often hard to disentangle from critiques of, or fears generated by, the international legal regimes constructed to protect it. Defenders of the TPP's investment chapter argue that the legitimate concerns about the negative externalities of FDI are taken care of through each of its prospective party's schedules. These state specific schedules include sector-specific exceptions from the treaty's guarantees of entry or national treatment. ${ }^{66}$ TPP critics are likely to see the treaty, including the limited exceptions permitted in its schedules, as being insufficiently sensitive to the needs to enhance FDI's positive externalities while reducing its negative ones.

The TPP's investment chapter is in the "reform it, don't end it" mode that has been followed by the United States for the past 20 years, as the promises and hazards of ISDS have become clearer. Its

64 Annie Hall (Film, Metro-Goldwyn-Mayer Studios, 1977).

65 See Jose E Alvarez The Public International Law Regime Governing International Investment (Martinus Nijhoff Publishers, Leiden (Netherlands), 2011) at 16-24.

66 Some of the more finely grained critiques of the TPP's investment chapter question whether New Zealand's schedules go far enough in the direction of protecting the government's discretion with respect to the entry of foreign capital: see Kawharu, above n 27. 
form and essential content follows the outlines set by the United States-Argentina BIT. ${ }^{67}$ Like that treaty, and United States investment treaties since, it too contains the same essential investor protections against discrimination, along with the "absolute" (non-relative) right of fair and equitable treatment (FET), free transfers, and limitations on performance requirements. ${ }^{68}$ But, like investment protection treaties concluded by the United States since it became a leading respondent state under NAFTA, with some 18 investor claims (all unsuccessful) under its belt, ${ }^{69}$ the TPP's investment chapter, as noted in more detail below, narrows most of the rights accorded foreign investors, expands the room for sovereign policy space for respondent states, and restricts the delegation of power accorded to investor-state arbitrators as compared to the earliest United States BITs. Whether one thinks that this reform-minded investment chapter constitutes a new "gold standard" or something a great deal less wonderful may turn on where one sits on the relative merits of incoming capital flows to begin with. It is also likely to turn on where priorities lie with respect to balancing each of the five tensions enumerated above.

Mainstream economists, members of the United States Business Roundtable or the New Zealand International Business Forum respectively, and market oriented politicians (like the newly elected President of Argentina) are likely to see the reform-minded TPP as satisfying a new golden mean with respect to these tensions. Those far more sceptical of the virtues of the international marketplace and of the place of ISDS within it, such as President Correa of Ecuador, Professors Jane Kelsey or Eyal Benvenisti, dissenting economists like Jeffrey Sachs or Joseph Stiglitz of Columbia University, or NGO critics like Lise Johnson of the Vale Columbia Center on Sustainable Development, see the TPP's investment chapter, as Ms Johnson has already indicated, as "entrenching" rather than truly reforming the "flawed" international investment system. ${ }^{70}$ In terms of the five tensions enumerated above, critics of the TPP's investment chapter see it as skewed in favour of global corporate capital, as promoting FDI at the expense of protecting national business, as extending protections to FDI (and FDI home states) rather than attempting to maximize the

67 Treaty between the United States of America and the Argentine Republic Concerning the Reciprocal Encouragement and Protection of Investment (adopted 14 November 1999, entered into force 20 October 1999), art XI [United States-Argentina BIT].

68 Indeed, the TPP's limitations on performance requirements are the considerably more developed prohibitions contained in more recent United States treaties, rather than the extremely limited limitation contained in the original United States-Argentina BIT, above n 67, art II(5). This is one of the few instances where the TPP provides investors greater protections than were extended under early United States BITs.

69 For a listing of the claims filed against the United States under the NAFTA, see United States Department of State "Cases Filed Against the United States of America" <www.state.gov>.

70 Lise Johnson and Lisa Sachs "The TPP's Investment Chapter: Entrenching, Rather than Reforming, a Flawed System" Vale Columbia Center on Sustainable Investment (Policy Paper, May 2015). Those who express scepticism of the benefits of the TPP are likely to be critical of free trade agreements generally or at least of those that incorporate ISDS: see for example, Kelsey, above n 37; Joseph Stiglitz Globalization and its Discontents (WW Norton, New York, 2002); and Johnson, Sachs and Sachs, above n 62. 
benefits they offer to host states, and as encouraging a race to the bottom in terms of host country policy space. This is what TPP critics mean when they charge the treaty with showing greater respect for property rights than for democratic principles or the principle of sovereign equality.

One's stance towards the TPP may turn on whether one is, by nature or nurture, disposed to be a "little Conservative" or a "little Liberal."71 But whether one thinks the TPP's investment chapter is the gold standard may also be the product of expectations. If one expected the TPP negotiations to produce a state of the art investment treaty, that goal was achieved. The TPP is the latest thing in a traditional investment protection treaty. As is further elaborated below, it is the latest word in treaty texts that have gone from the exceptionally strong investor rights of the United States Model BITs of 1984 and 1987 to the more complex regional package deals struck by the three NAFTA parties to the more "sovereign-sensitive" provisions of the United States Model BIT of 2012 and contemporary United States FTAs. ${ }^{72}$ NAFTA trimmed some investor rights and restored the capacity of the state parties to re-examine those rights through joint "commission" interpretations binding on investor-state arbitrators. ${ }^{73}$ The more cautionary stance taken in NAFTA - the first investment protection treaty concluded between two capital exporting nations - began a process of adaptation in United States investment protection agreements as the United States encountered challenges brought by Canadian investors under NAFTA and in response to other ISDS rulings involving other states. The TPP replicates many of the provisions of the latest generation of United States (and to some extent Canadian) investment protection treaties. Its contents reflect that of the 2004 and 2012 United States Model BIT texts and treaties concluded under their influence, including the investment chapters of recent United States FTAs. ${ }^{74}$ Some of these textual changes have appeared in New Zealand's investment treaties prior to the TPP, such as the Protocol on Investment to the New Zealand-Australia Closer Economic Relations Trade Agreement. ${ }^{75}$ But that agreement did not include ISDS and also included some tweaks that are reminiscent of provisions

71 See William Schwenck Gilbert and Arthur Seymour Sullivan Iolanthe (Opera, 1882): "I often think its comical ... /How Nature always does contrive ... /That every boy and every gal/That's born into the world alive/ Is either a little Liberal/Or else a little Conservative". For a more intellectual exploration of how "nature" may influence ideology, see for example Alford Hibbing Predisposed: Liberals, Conservatives, and the Biology of Political Differences (Routledge, Abingdon-on-Thames, 2013).

72 Alvarez, above n 47.

73 At 10

74 At 9-12 and Annex A (table comparing the 1984 and 2004 United States BITs). For the text of the 2004 United States Model BIT see <www.state.gov/documents/organization/117601.pdf>. For the text of the 2012 United States Model BIT see <www.state.gov/documents/organization/188371.pdf>.

75 Protocol on Investment to the Australia-New Zealand Closer Economic Relations Trade Agreement (signed 16 February 2011). 
found in the European Union-Canada FTA, the Comprehensive Economic and Trade Agreement (CETA). ${ }^{76}$

The annex to this essay, containing recent iterations of the FET clause, illustrates how much the TPP's investment chapter owes to post-NAFTA United States treaty practice. As investment lawyers recognise, the FET clause is the heart of most investment protection treaties and perhaps the investment regime as a whole. Nearly all investment protection agreements have an express reference to FET and indeed, to the extent FET is considered part of customary international law, all treaties that include a reference to protecting investors "under international law" might be deemed to include this right. The FET guarantee has become more important in practice as states have turned away from the outright nationalisations and expropriations which once upon a time constituted the core risks faced by foreign investors. FET is, in addition, the treaty guarantee that is the most invoked by investors and, most importantly, is the most likely to be successful on their behalf. ${ }^{77}$ While references to "fair and equitable treatment" date back centuries, that guarantee did not receive sustained attention from adjudicators until investor-state claims began being heard in significant numbers starting in the late 1990 s. $^{78}$ Today, with some 600 investor-state arbitral claims either being heard or already decided, this provision has drawn prominent attention at the highest levels of government.

Of course, FET may be of use to an investor even if a treaty does not include it, but another investment treaty concluded by the host state does, and the investor has the right to claim FET protection through the magic of a most favoured nation treatment clause. ${ }^{79}$ In addition, in some treaties, like the United States-Argentina BIT quoted in the annex, there is a reference to FET in a treaty's preamble as well as its substantive text. ${ }^{80} \mathrm{~A}$ preamble's FET reference may facilitate a finding by an arbitrator that this guarantee is part of a treaty's essential object and purpose. It may encourage a finding that the good faith interpretation of the treaty's object is to provide investors with fair treatment; it may enable interpretations that in case of ambiguity the question should be

76 Government of Canada "Canada-European Union: Comprehensive Economic and Trade Agreement (CETA)" <www.international.gc.ca>. As noted below, this CETA text, released in February 2016, now replaces resort to ISDS with an international investment court comparable to that proposed by the European Union in the on-going negotiations for the Trans-Atlantic Partnership: see arts 8.23-8.31.

77 See Rudolf Dolzer and Christoph Schreuer Principles of International Investment Law (1st ed, Oxford University Press, Oxford, 2008) at 119-149.

78 See Martins Paparinskis The International Minimum Standard and Fair and Equitable Treatment (Oxford University Press, Oxford, 2013).

79 For the role of the most favoured nation clause in "multilaterialising" the international investment regime, see Stephan Schill The Multilateralization of International Investment Law (Cambridge University Press, Cambridge, 2009) at 121-196.

80 United States-Argentina BIT, above n 67, preamble, at [4]. 
resolved in favour of protecting investments and investors. ${ }^{81}$ For these and other reasons, the meaning of FET has often featured prominently in debates about the merits of the international investment regime.

To proponents of these treaties and to investor claimants the FET clause is useful because of its flexibility. Indeed, some have suggested that the FET provision provides invaluable gap-filling protection to an investor who fails to convince a tribunal that he or she has been the victim of discriminatory treatment or an expropriation. But to critics of the investment regime, this is precisely the problem: a reference to FET provides an imprecise right to foreign investors that simultaneously provides little guidance to state regulators, delegates considerable "law-making" power to creative investor claimants and arbitrators, and enables foreigners to claim protections not available to national investors under national law. ${ }^{82}$

As the annex illustrates, the FET provision has evolved over time, even with respect to the limited treaty parties reflected in that annex. Indeed, it is probably the investment guarantee that, at least in United States investment treaty practice, has changed the most over the past 20 years, with the United States' much altered expropriation provision being a close second. ${ }^{83}$ The FET guarantee is an absolute right in the sense that it does not require comparison to how a domestic investor is treated. Proving an FET violation does not require a showing of discriminatory treatment, but much else about FET has generated debate among scholars and arbitrators. Tomes have been written on alternative interpretations of this seemingly simple phrase. ${ }^{84}$ This essay limits itself to the following five illustrative possibilities. ${ }^{85}$

(1) FET means only those guarantees that customary international law extends under the minimum standard of treatment of aliens. On this view, FET tends to be equated with the right to procedural due process; that is, a violation of FET requires a denial of justice. This is the minimalist view of FET accepted even by tribunals that reject variations $2-5$ below. However, substantial debates have ensued about what constitutes a contemporary denial of justice or violation of the international minimum standard.

(2) FET may include, in addition to (1) above, a host state's violations of its other international legal obligations. This would mean that if a host state can be shown to be violating the WTO's rules in its treatment of a foreign investor, that violation can be the subject of an

81 See generally Dolzer and Schreuer, above n 77, at 122.

82 See for example Van Harten, above n 21, at 86-90.

83 See generally Alvarez, above n 47.

84 See for example Paparinskis, above n 78.

85 For a fuller discussion, see Alvarez, above n 65, at 177-246. 
ISDS claim (as well as possibly a WTO claim to the extent the investor's home state wishes to pursue it).

(3) Whether or not one accepts (2) above, a violation of FET may emerge from a host state's violations of its own law. Tribunals that take this view may do so on the premise that violations of a state's own law violates the legitimate expectations of investors, or on the premise that a host state that violates its own law is presumptively not acting in good faith. On this view, FET becomes a substantive guarantee and not only a procedural one.

(4) FET requires consideration of whether a host state has treated an investor fairly along with a distinct inquiry about whether it has treated the investor equitably. Violations of either are not restricted to departures from a host state's national or international obligations. On this view, the FET clause is a de facto delegation of authority to arbitrators to determine the relative equities on both sides, including consideration of whether a host state or an investor is otherwise acting in good faith.

(5) Reference to FET as such does not have a single core meaning. The meaning and scope of this guarantee varies depending on the treaty text, including the context of the provision, the negotiating history of the particular treaty and all the other factors authorised under the traditional rules for treaty interpretation.

While (1) above has been the most common formulation of FET among arbitrators and scholars, it has not displaced (5); that is, an FET clause that includes, apart from a bare reference to fair and equitable treatment, other language is likely to be interpreted in light of that context. This is certainly the operating assumption of those who drafted the FET clauses contained in the annex, including the TPP's.

The United States-Argentina BIT text, based on the United States Model BITs of 1984 and 1987, quoted in the annex, provides the most investor-protective formulation of FET in United States treaty practice. Under this clause, FET is a distinct additional right accorded to investors, above and beyond "full protection and security" and any entitlements under international law. This formulation of the right to FET does not equate it with customary international law or even with a state's other international obligations, but situates the right in a complex web of additional investor rights, including rights to be free of "arbitrary and discriminatory measures" as applied to a wide range of activities (management, operation, and so on) associated with an investment (and not just the direct decision to invest). In this treaty, the right to FET is also embedded in a clause that also compels states to "observe any obligation it may have entered into with regard to investments", an ostensible umbrella clause whose wide scope would appear to embrace a state's contracts entered into with investors but which may also embrace other representations made by a state to investors whether contained in licenses, oral statements, or perhaps the state's general laws or international 
commitments. ${ }^{86}$ Not surprisingly, this formulation of FET, in context and interpreted in light of the ejusdem generis canon of construction, can easily be treated as designed to protect investors' legitimate expectations. Such expectations are, after all, the apparent rationale connecting the various rights enumerated alongside the right to FET. ${ }^{87}$

By contrast, the FET clause in the Argentina-Australia BIT of $1995^{88}$ in the Annex is the simplest, insofar as it says nothing about the possible connections between FET and other parts of international law, customary or otherwise, and provides no other helpful context at least within the FET clause itself. Without more, this clause is not necessarily more solicitous in terms of protecting the host state's regulatory space. Indeed, its simplicity provides arbitrators, particularly those not apt to adhere to prior arbitral rulings on point, with the most discretion. When FET stands alone, as in this text, arbitrators charged with interpreting and enforcing it have, at least in theory, all five interpretative possibilities surveyed above to choose from.

But the 1994 NAFTA version of the FET clause in the annex cabins that discretion in one respect: it affirms that investors must be treated "in accordance with international law" and indicates that international law includes the FET guarantee. This phrasing appears to suggest that FET is not some self-standing right apart from general international law (including the international minimum standard of treatment) but is part and parcel of international law. Since at least one NAFTA arbitral tribunal was not convinced that NAFTA drafters intended to cut back so dramatically on the FET right that at least one of NAFTA parties had previously concluded, on July 31, 2001 the NAFTA parties released their joint interpretation of NAFTA's FET clause, quoted in the annex. ${ }^{89}$

86 Notably, this formulation does not clarify whether the clause protects investors only with respect to specific representations made by states to specific investors or whether general representations should be included in the duty to observe any obligation. It also seems to protect all types of assurances "entered into" by a host state and a foreign investor and not only the investment authorizations and investment agreements contemplated by the TPP's art 9.1. For a review of the interpretation of such umbrella clauses see Andrew Newcombe and Luís Paradell Law and Practice of Investment Treaties (Kluwer Law International, The Hague, 2009) at 437-479.

87 See generally Dolzer and Scheuer, above n 77, at 133-140.

88 Agreement Between the Government of Australia and the Government of the Argentine Republic on the Promotion and Protection of Investments [1995] ATS 4 (signed 23 August 1995, entered into force 11 January 1997).

89 See NAFTA Free Trade Commission "Notes of Interpretation of Certain Chapter 11 Provisions" Nafta Claims (31 July 31 2001) <www.naftaclaims.com>. For a concise account description of the evolution of this interpretation and its effect on a pending NAFTA case see David Gantz "Pope \& Talbot Inc v Canada" (2003) 97 AJIL 937. 
This controversial Commission Interpretation, binding on NAFTA investor-state arbitrators, has been criticised as an unauthorised amendment of NAFTA and not a mere clarification. ${ }^{90}$ Whether or not it was a faithful interpretation of NAFTA's FET clause, it undoubtedly narrowed the interpretation of the FET guarantee from that as provided under prior United States BITs, including the United States-Argentina BIT. The Commission Interpretation, which as the annex indicates, influenced subsequent versions of the FET clause in United States treaties (and indeed the treaty texts of some other BIT parties, including China's), ${ }^{91}$ states that FET prescribes the international minimum standard of treatment under customary law. It also indicates that violations of other treaties (including other parts of NAFTA itself) do not "establish" a breach of FET. ${ }^{92}$

By the time the United States drafted its 2004 Model BIT three years later, the minimum standard of treatment became the title for the old FET clause. As the annex indicates, the 2004 Model incorporates NAFTA's formulation of FET in its first paragraph, but goes on to clarify, "for greater certainty", that neither FET nor full protection and security extend any greater rights than that accorded under the customary international law minimum standard of treatment of aliens, and that FET "includes" denial of justice "in accordance with the principle of due process". Finally, the 2004 Model incorporates into its text the final part of the NAFTA Commission Interpretation from 2001, indicating that breaches of other treaties does not establish a breach of this provision. In response to suggestions in several NAFTA arbitral rulings that the customary international law minimum standard has evolved (while relying on prior arbitral rulings in support), the 2004 Model goes a step further and includes an annex purporting to confine the meaning of "customary international law" and specially of "the international minimum standard of treatment of aliens". The former is stated to result from state practice followed by a sense of legal obligation. The latter protect the "economic rights and interests of aliens".

Prior United States FET clauses explain nearly every aspect of the TPP's FET provision. Like the 2004 United States Model BIT, the TPP's equivalent provision, at art 9.6, is now entitled "minimum standard of treatment". Its first paragraph duplicates the NAFTA provision on point, as well as the first paragraph of the 2004 Model. Its second and third paragraphs replicate the second and third paragraphs of the 2004 Model. In addition, the TPP's annex on customary international law

90 See for example Gabrielle Kaufmann-Kohler "Interpretive Powers of the Free Trade Commission and the Rule of Law" in Emmanuel Gaillard and Frédéric Bachand (eds) Fifteen Years of NAFTA Chapter 11 Arbitration (Juris Publishing, Huntington (NY), 2011).

91 See Alvarez, above n 47, at 12.

92 Some arbitral tribunals have nonetheless permitted investors to argue that a host state's violations of its other treaties, including WTO commitments, is a relevant consideration in determining that a violation of FET occurred even though such violations do not alone "establish" that the FET obligation has been breached. This may be the case where a tribunal believes that it protects the investors' legitimate expectations to be treated in accordance with the host state's national and international legal obligations. See for example Newcombe and Paradell, above n 86, at 285. 
replicates, with one minor deviation, the comparable definitional annex from the 2004 Model. The only departure from the prior United States text in that annex is that the international minimum standard of treatment of aliens now includes "all customary international law principles that protect investments of aliens", a circular definition that seems to be broader than the original United States text insofar as it is not limited to the "economic interests of aliens" (but may be narrower depending on what is meant by rights that protect "investments of aliens"). ${ }^{93}$

The one clear departure in the TPP is art 9.6(4), which uses the familiar United States phrase "for greater certainty" to introduce a limitation that was certainly not clear in either prior FET clauses or the majority of arbitral rulings on point. Article 9.6(4) seems to be saying that the violation of an investor's expectations cannot be the only reason ("the mere fact") for finding a breach of FET, even if violating those expectations causes tangible loss or damage. This poorly worded clause has not appeared in prior United States Model texts and appears to be responsive to provisions like that in the CETA text provided in the annex, at art 8.10(4). The CETA text seeks to limit the scope of legitimate expectations as deployed by some arbitral tribunals. It clarifies that only specific representations by a host state (as in a contract) that actually induces an investor to invest and on which the investor relies can be taken into account. The TPP's comparable clause takes the opposite tack: it purports not to define the scope of legitimate expectations but to modify the relevant evidentiary burdens, but only with respect to "expectations" (which are not defined or clarified). Subject to this exception, the TPP's FET clause appears to be the latest iteration of that clause in the United States' most recent treaties.

In following this path, the negotiators of the TPP rejected some alternatives suggested by the CETA text set out in the annex. The CETA equivalent provision does not equate FET to customary international law or the international minimum standard and does not purport to define these terms. It provides, on the other hand, a closed list of what constitute FET breaches in art 8.10(2)(a)-(f) that might be seen as designed to narrow the interpretative discretion accorded to arbitrators. By contrast, the TPP includes, consistent with prior United States practice, only the first item (2)(a) from the CETA text, namely denials of justice, but suggests that other kinds of FET breaches may exist that it does not enumerate. Those looking for a narrower version of the FET guarantee might prefer the CETA's alternative to the open-endedness of the TPP's art 9.6(2)(a). On the other hand, the CETA enumeration at art 8.10(2)(a)-(f), notwithstanding some efforts to cabin breaches that might have been included under the expansive United States-Argentina BIT (for example, restricting investors to bringing claims only for "manifest" arbitrariness), includes some very expansive possibilities, such as "abusive treatment of investors". Whether the CETA's FET clauses actually closes the door on expansive interpretation remains to be seen.

93 It is not clear whether this broader language is intended to extend protection to, for example, the human rights of aliens. 
At the same time, as the CETA text indicates, the TPP is not alone in following a path initially blazed by the United States, including in its NAFTA practice. The CETA's closed list at art 8.10(2)(a)-(f) appears to be an effort to codify the most cited paragraph from a NAFTA ruling, Waste Management $v$ Mexico. ${ }^{94}$ The CETA text also adopts the NAFTA's innovation of reintroducing a role for its state parties in defining, from time to time, the meaning of the FET guarantee in para 3, while para 6 essentially replicates art 5(3) from the 2004 United States Model.

There are many other examples in the TPP of provisions that either reflect or even go beyond more recent United States treaty practices in order to re-calibrate the balance of investor rights versus state's right to regulate. The TPP's definition of investment narrows the property rights that it protects by making clear that only tangible assets involving a commitment of capital entailing an assumption of risk can be included. ${ }^{95}$ The TPP also narrows nearly all of the substantive protections accorded to foreign investors from the high point of those protections (as under the United StatesArgentina BIT), apart from FET. While the right to national and most favoured nation (MFN) treatment extends to the right of entry, the TPP permits individual TPP parties to opt out of ISDS with respect to such claims and, thus far, Australia, Canada, New Zealand and Mexico have all decided to do so. ${ }^{96}$ As with United States treaties after NAFTA, the umbrella clause extending protections for "obligations" entered into by host states, originally part of the FET obligation in the United States-Argentina BIT, has been replaced by a more limited obligation that permits investors to bring claims for breaches of "investment authorizations" and some "investment contracts" with TPP party states. ${ }^{97}$ The TPP's national treatment protection clarifies that consideration of whether a foreign investor is denied such treatment turns on an examination of "the totality of the circumstances, including whether the relevant treatment distinguishes between investors or investments on the basis of legitimate public welfare objectives" and not a more mechanical

94 Waste Management Inc v United Mexican States (Award) ICSID ARB(AF)/00/3, 30 April 2004 at [98].

95 TPP, above n 3, s 9.1 (definition of investment). This nods to the "Salini factors" developed in investor-state case law which attempted to restrict the meaning of protected investment for purposes of the ICSID Convention: see for example Dolzer and Schreuer, above n 77, at 60-71. This definition can be compared to the comparable provision in the United States-Argentina BIT which provided only a general circular definition of investment ("investment means every kind of investment"), without reference to "asset", "commitment of assets" or "assumption of risk": see United States-Argentina BIT, art 1(a). The TPP also suggests that mere contracts for the sale of goods are "less likely" to have the characteristics of investment at $\mathrm{n} 2$.

96 TPP, above n 3, annex 9-H.

97 Article 9.1 defining both "investment authorizations" and "investment agreements" with the latter limited to contracts with a TPP host state in relation to the exploitation of natural resources, the operation of public utilities, and government procurement; and art 9.18(1) permitting investors to bring claims for breaches of investment authorizations and agreements. 
approach to interpreting whether a foreign and national investor are in "like circumstances". ${ }^{98}$ Its MFN treatment provision does not encompass dispute settlement procedures or mechanisms, thereby preventing investors from claiming more beneficial provisions on ISDS extended in TPP parties' prior treaties. ${ }^{99}$ Beyond the limitations on FET discussed earlier, that guarantee does not extend to some forms of restructured public debts which can be subject to an investor claim only if discriminatory treatment is shown. ${ }^{100}$

The TPP's guarantee of prompt, adequate and effective compensation upon expropriation is essentially derived from the United States' most recent iterations of this provision. It includes, in Annex 9-B, a considerable narrowing of the potential for claims based on regulatory or indirect takings of property, including a requirement of case-by-case balancing of three factors drawn from a famous United States Supreme Court case and a clarification, indicating, "for greater certainty", that non-discriminatory regulatory actions taken for legitimate public welfare objectives do not, "except in rare circumstances", constitute indirect takings. ${ }^{101}$ But it also adds to those assurances of greater policy space, clarifications not previously reflected in United States treaty practice. ${ }^{102}$

As do recent United States treaties, the TPP discourages some forms of "nationality" or "treatyshopping" by specifying that its benefits do not extend to those enterprises which have only a paper presence in the other TPP treaty party, that is, have "no substantial business activities" in another TPP party state other than the party against which a claim is brought. ${ }^{103}$ In accordance with post-

98 Article 9.4 and n 14. This goes beyond the United States Model BIT of 2012, above n 74, which has no such clarification or limitation.

99 TPP, above n 3, art 9.5(3). This takes a more a narrower approach to the MFN than had been taken by some arbitral tribunals: see Dolzer and Schreuer, above n 77, at 253-257.

100 TPP, above n 3, annex 9-G, at [2]

101 Annex 9-B. This is a response to considerable ambiguity arising with respect to the handling of prior "regulatory takings" by prior ISDS tribunals, including widespread dissatisfaction with the dicta expressed in NAFTA's Metalclad ruling and a desire, by United States treaty drafters, to return to the security provided under the leading United States Supreme Court authority on takings: see, for example Dolzer and Schreuer, above $\mathrm{n}$ 77, at 92-106 and 109-114. The three factor test contained in the TPP's annex 9-B, at [3(a)(i)-(iii)] is taken from the famous ruling interpreting the "takings clause" of the United States Constitution rendered by the United States Supreme Court in Penn Central v City of New York 438 US 104 (1978).

102 It ties the concept of "public purpose" to customary international law: see TPP, above n 3, art 9.7 and n 17 . It also indicates that the second factor in the three factor test applicable to indirect takings, which requires examining whether an investor's investment-backed expectations are "reasonable", depends on "whether the government provided the investor with binding written assurances and the nature and extent of governmental regulation or the potential for government regulation in the relevant sector": see TPP, above n 3, annex 9-B and $\mathrm{n} 36$. The TPP also adds considerable detail to what may constitute permissible regulatory actions to protect public health: see TPP, above $\mathrm{n} 3$, annex 9-B and n 37 .

103 TPP, above n 3, art 9.14(1)(b). For discussion of the treaty-shopping risks that this clause seeks to address see for example Dolzer and Schreuer, above n 77, at 49-52. 
NAFTA United States treaty practice, the TPP includes a clause permitting states to take environmental, health or other regulatory measures "otherwise consistent" with its investment chapter, but goes beyond United States prior practice by including another clause that reaffirms the importance of each party "encouraging" the adoption of corporate codes of social responsibility. ${ }^{104}$

The TPP also borrows heavily from the United States treaty toolkit with respect to fixing the alleged rule of law flaws of ISDS. It anticipates that respondent states may file certain counterclaims, ${ }^{105}$ requires claimants to state the basis of their claims from the outset, ${ }^{106}$ requires claims to be brought within three years and six months of the alleged breach, ${ }^{107}$ anticipates the acceptance of amicus briefs by investor-state arbitrators, ${ }^{108}$ provides an expedited process for the handling and prompt dismissal of frivolous claims as well as those challenging jurisdiction, ${ }^{109}$ clarifies that the burden of proof rests on the investor with respect to proving all elements of its claim, ${ }^{110}$ adopts a WTO-inspired procedure enabling the litigants to get a "first look" at the draft arbitral award prior to its issuance, ${ }^{111}$ anticipates that the TPP parties may establish an appellate mechanism, ${ }^{112}$ requires transparency with respect to all documents filed in the course of investorstate arbitration, ${ }^{113}$ requires ISDS arbitrators to respect any binding interpretations of the treaty issued by the TPP parties, ${ }^{114}$ permits the disputing parties to consolidate claims that share a common question of law or fact, ${ }^{115}$ and imposes limits on damages with respect to claims alleging denial of entry. ${ }^{116}$ In a departure from prior United States treaty practice and presumably responding

104 TPP, above n 3, arts 9.16 and 9.17. Interestingly, both of these articles are included in section A of the investment chapter which means that they are subject to investor-state dispute settlement under art 9.18.

105 Article 9.19(2).

106 Article 9.19(3).

107 Article 9.21(1)

108 Article 9.23(3)

109 Articles 9.23(4) and (5). It also provides the arbitrators with the option of awarding the prevailing party costs in such proceedings: see art 9.32(6).

110 Article 9.23(7). This provision had not previously appeared in United States treaty practice.

111 Article 9.23(10).

112 Article 9.23(11).

113 Article 9.24. In a further departure from prior United States treaty practice, the transparency requirements now extend to any available minutes or transcripts of the hearings of the tribunal: see art 9.24 (1)(d).

114 Article 9.25(3).

115 Article 9.28

116 Article 9.29(4) requiring that any the only damages that may be awarded in such cases be limited to those that the claimant proves were sustained in the attempt to make the investment and proximate to the breach. 
to criticisms of ISDS with respect to the current handling of challenges to arbitrators, the TPP anticipates that its state parties will "provide guidance on the application" of a Code of Conduct for Dispute Settlement Proceedings. ${ }^{117}$ The TPP also narrows the scope of ISDS in other respects, including by permitting state parties to opt out of it altogether with respect to claims arising from their tobacco control measures. ${ }^{118}$ The TPP also includes the latest versions of United States general exceptions from the provisions of the investment chapter, including an exception for measures that parties "consider necessary for fulfilment of its obligations with respect to the maintenance or restoration of international peace or security, or the protection of its own essential security interests". 119

As the above summary suggests, the TPP's investment chapter largely replicates recent United States treaty practice. A recent comparison of treaty texts by two scholars, finding that that 82 per cent of the text of the TTP's investment chapter is taken from the United States-Colombia FTA's investment chapter (and that the TPP's investment chapter text has a 60 per cent similarity with NAFTA's), strongly supports this conclusion. ${ }^{120}$ Of course, assuming this linguistic analysis is correct, 18 per cent of the TPP's investment chapter does not replicate recent United States practice and those differences could prove determinative with respect to winning and losing prominent investor claims. ${ }^{121}$

It is impossible to predict whether the TPP's investment chapter will, should it go into effect unchanged, lead to eventual case law comparable to that produced to date under NAFTA or other treaties with similar or even identical provisions. Much will depend on the claims brought, the arbitrators selected, as well as matters that are not yet clarified in the existing text (such as the contents of the anticipated Code of Conduct for arbitrators). ${ }^{122}$ The parts of the investment chapter

117 Article 9.22(6).

118 Article 29.5 on tobacco control; and art 29.4 requiring pre-screening by the respective Party's tax authorities for claims claiming expropriation based on tax measures. As noted, a side letter to the TPP also ensures no ISDS as between the investors of Australia and New Zealand.

119 Article 29.2. Other exceptions permitted include "temporary safeguard measures" on transfers of capital (art 29.3), and measures deemed necessary by New Zealand to fulfil the Treaty of Waitangi (art 29.6). In addition, the TPP's Financial Services Chapter includes exceptions taken for "prudential" reasons to, among other reasons, "ensure the integrity and stability of the financial system" as well as non-discriminatory measures in pursuit of monetary or exchange rate policies: see TPP Financial Services Chapter, art $11.11(1)-(2)$.

120 Wolfgang Alschner and Dmitriy Skougarevskiy "The New Gold Standard? Empirically Situating the TPP in the Investment Treaty Universe" (23 November 2015) The Graduate Institute of International and Development Studies <www.repository.graduateinstitute.ch>.

121 Indeed, one critic of the significance of the 82 per cent finding has pointed out that chimpanzees and humans share 98 per cent of the same DNA but that two per cent in that instance makes all the difference.

122 See TPP, above n 3, art 9.21(6). 
that do not draw from United States practice - such as its language under FET concerning the meaning of legitimate expectations, its statement that MFN does not apply to dispute settlement, or its provision on corporate social responsibility - may prove to have considerable impact.

The TPP also appears to leave more room than prior United States BITs or FTAs for each of its state parties to make exceptions to its terms, and this too may have a considerable impact on whether it will generate the sovereign backlash against ISDS that has been evident elsewhere. The TPP's parties have considerable options, for example, with respect to how to deal with their own prior investment protection treaties and whether, for example, investors under the TPP will be able to enhance their rights by drawing from any better treatment accorded to others in these older treaties through MFN. ${ }^{123}$ This scope for discrete party exceptions even applies, as noted, with respect to whether tobacco control measures will be subject to investor challenge through ISDS. To the extent the TPP does not avoid overlap with the 35 investment agreements, including NAFTA, concluded among a subset of TPP parties, it is likely to encourage, not eliminate, the prospect of forum shopping, resorts to MFN or normative conflicts among these treaties. ${ }^{124}$

For this reason, it is not clear that the TPP is likely to harmonise global investment standards and thereby facilitate the conclusion of a multilateral investment treaty. ${ }^{125}$ At the same time, thanks to the TPP, three pre-existing investment treaties, between Australia and Japan, Malaysia and the United States respectively, which did not originally have ISDS, would, if the TPP comes into effect, provide investors from those countries access to ISDS. Although, as noted, Australia and New Zealand's FTA from 2011 will not be affected, given those two countries decision to opt out of the TPP's ISDS as between themselves, the TPP is still a significant departure from Australia's recent practice with respect to ISDS (at least with respect to Australia's relations with the other TPP partners apart from New Zealand).

It is also possible that given the exceptions from the investment chapter taken by the 12 TPP parties individually, the TPP will not produce the extent of investment liberalisation among its parties that some proponents of the treaty anticipated. And yet, the text of the investment guarantees accorded in the TPP that remain subject to ISDS cannot be described as lowest-common denominator investor rights. Although the TPP narrows most investor guarantees as compared to the high point of early United States BITs, that narrowing lies within the parameters of the generally high standards of investment protection that have historically characterised United States treaty practice. This is a treaty that accords foreign investors absolute rights (for example FET, full protection and security, compensation for direct expropriations, bans on multiple performance

123 See for example Alschner and Skougarevskiy, above n 120, at 21-24.

124 At $21-24$.

125 At $26-28$. 
requirements, and free transfers of capital) and relative rights (for example national and MFN treatment), while also responding at the margins to arbitral decisions that have alarmed host states.

The TPP's investment chapter is a relatively balanced instrument for a reason. It is, after all, a treaty concluded among states that experience, for the most part, bidirectional investment flows even if in some instances (as with respect to New Zealand) those flows are disproportionately inward directed. It should not surprise anyone that the TPP seeks to balance the needs of capital exporters desiring to protect the rights of their investors abroad with the needs of capital importers which, as host states, still need to be able to regulate to protect the public interest. ${ }^{126}$ The TPP's investment chapter converges around high United States standards for investment protection, host state flexibility, and investor-state arbitration. ${ }^{127}$ That trifecta is not achieved in the broader universe of investment treaties elsewhere, including in the Asian region.

Of course, if the TPP's text largely converges around the practice of one of its 12 parties; that may be, to its critics, itself a problem insofar as it supports Benvenisti's "divide and conquer" hegemonic account. ${ }^{128}$ And, if what one expects from a "gold standard" is not just a treaty that reflects current trends but one that ends, for good, the second-guessing of host states' regulatory practices and does not provide foreign investors with any greater rights than those given to national investors, this is not such a treaty.

Consider for example, the controversial arbitral award made in favour of the United States investor Bilcon in Bilcon $v$ Canada, a NAFTA award of March 17, 2015. ${ }^{129}$ In that case, the majority - Bruno Simma J (formerly of the ICJ) and Professor Bryan Schwartz - over the dissent of Professor Donald McRae, ruled in favour of the mining company, which had been denied the right to engage in a quarry project in Nova Scotia after an environmental review by the federal and provincial authorities. The decision turned substantially on the interpretation of the FET provision in NAFTA, identified in the annex. The Tribunal agreed that this provision is identical to rights to the international minimum standard under customary international law but noted that, in accord with a number of prior NAFTA decisions, that standard has evolved over time so that it no longer requires proof of bad faith, wilful neglect of duty, or grossly unfair or a manifest or outrageous failure of justice, but could be triggered by violations of due process. ${ }^{130}$ In accord with the warnings against relying exclusively on the investors' legitimate expectations (that now appears in the TPP's FET clause as discussed) and that to the extent those expectations exist these must be based on specific

126 At $13-16$

127 At 19 .

128 See Benvenisti, above n 14.

129 Bilcon v Canada (Jurisdiction and Liability) PCA 2009-04, 17 March 2015.

130 At [433]-[454]. 
representations by Canada on which the investor relied (see the language in CETA), the Tribunal concluded that it could still take into account the reasonable expectations of the investor that they would indeed be permitted to operate their quarry based on brochures and other statements by Canadian officials. ${ }^{131}$ The Tribunal found a violation of the FET provision based on the fact that the Canadian environmental review board relied on an unclear concept of "community core values" not specifically mentioned in Canadian law and departed from its usual procedure of suggesting mitigation procedures prior to issuing a final denial to a project. ${ }^{132}$

Dissenting arbitrator McRae, a prominent Canadian academic in both trade and investment, argued that the actions of Nova Scotia officials in encouraging investment in mining were irrelevant to the alleged treaty violation, that consistency with community core values was indeed part of Canadian law and anticipated that the investor engage effectively in consultations with Aboriginal peoples, fishers and others in the affected community, and that the Tribunal's ruling otherwise appeared to be based simply on their view - right or not - that Canadian laws had not been properly applied despite the discretion normally accorded to the environmental review process. ${ }^{133}$ To McRae, the reviewers of the project took a principled position that was in accord with due process, with the socio-economic considerations that they were charged with considering, and which could not be seen as arbitrary, unfair or inequitable. ${ }^{134}$ McRae pointed out that by treating this as a treaty breach, the majority had introduced the potential for getting damages for action that under Canadian law does not provide a damages claim, thereby adding a further control over environmental review panels that does not exist under Canadian law. ${ }^{135} \mathrm{He}$ suggested that the decision would change the character of environmental reviews in Canada, since these are generally made up of scientists and environmental experts and not lawyers attentive to the nuances in language that his arbitral colleagues apparently now expected. ${ }^{136}$ McRae concluded that: ${ }^{137}$

... this is a significant intrusion into domestic jurisdiction and will create a chill on the operation of environmental review panels ... [It] is not only an intrusion into the way an environmental review process is conducted, but also an intrusion into the environmental public policy of the state.

131 At [455]-[474].

132 At [502]-[514], [530]-[543] and [546]-[547]

133 At [34] and [36]-[37] per Professor Donald McRae. In this connection, note that the recently "scrubbed" text of CETA, as released in February 2016, after the Bilcom ruling, now includes a purported clarification ("for greater certainty") indicating that "the fact that a measure breaches domestic law does not, in and of itself, establish a breach of [FET]": see Annex and CETA, above n 76, art 8.10(7).

134 Bilcon v Canada, above n 129, at [38] and [50]-[51].

135 At [48].

136 At [46]-[48].

137 At [48]-[49]. 
As Lise Johnson and Lisa Sachs point out, there is nothing in the TPP's FET clause that would prevent another arbitral award like Bilcon. ${ }^{138}$ To such critics, the TPP's efforts to narrow the guarantees offered to investors, including FET, in response to 15 years of ISDS case law, does nothing to reduce the risks of arbitral second-guessing at odds with a state's ability to protect public values. ${ }^{139}$ It does not eliminate the possibility of arbitral reliance on state representations that were never intended to be legally binding and that would probably not be deemed relevant to resolve contractual disputes under national law. It does not eliminate resort to investor expectations and does not render more precise how egregious a violation of due process needs to be to violate FET or how much customary international law has evolved and what is relevant to making that judgment other than the decisions of prior arbitrators under BITs and FTAs. ${ }^{140}$

Johnson and Sachs have a similar reaction to the other TPP efforts to re-calibrate the balance of investor and states' rights: art 9.16 does not, in their view, protect the states' right to regulate since all it does is clarify that states can take regulatory measures that are "otherwise consistent with the [investment] chapter". ${ }^{141}$ The TPP's provision that the claimant investor bears the burden of proof just recognises what is already the law; the rules on frivolous claims already appear in old treaties and do not fully protect states from such claims if arbitrators fail to use their powers; and its rule of law fixes of ISDS, nearly all familiar, do nothing to enable interested non-parties to intervene in these public interest cases, to provide the public with access to all relevant information - such as the settlements that states may enter into with investors in order to get rid of claims prior to an award or to enable a real second look at erroneous arbitral awards through any provision for appellate review. ${ }^{142}$ The TPP, in short, does little in their view to protect against potential regulatory chilling effects. Johnson and Sachs conclude that the TPP: 143

138 Johnson and Sachs, above n 70, at 8-11 arguing that the TPP's efforts to clarify the concept of nondiscrimination would not prevent Bilcon-type rulings and the bringing of "speculative" claims. Although Johnson and Sachs address the national treatment guarantee of NAFTA, their conclusion applies equally with respect to the TPP's FET revised guarantee.

139 Nor does the TPP ensure that investor claims will not challenge state measures of extraordinarily significant dimensions, such as a decision to eliminate its reliance on nuclear energy. See for example Nathalie Bernasconi-Osterwalder and Rhea Tamar Hoffmann "The German Nuclear Phase-Out Put to the Test in International Investment Arbitration? Background to the New Dispute Vattenfall v Germany (II), IISD" (June 2012) International Institute for Sustainable Development <www.iisd.org>.

140 Johnson and Sachs suggest that a better result would have been to eliminate the FET guarantee altogether or to make it subject only to state to state but not investor-state adjudication: see Johnson and Sachs, above n 70 , at 6 .

141 At 2.

142 At 4.

143 At 19 
... represent[s] just small tweaks around the margins ... At their core, ISDS and investor protections in treaties establish a privileged and powerful mechanism for foreign investors to bring claims against governments that fundamentally affect how domestic laws are developed, interpreted and applied, and sideline the roles of domestic individuals and institutions in shaping and applying public norms. For this reason, the TPP should drop ISDS altogether, or replace it with a new and truly reformed mechanism that addresses the myriad concerns that are still lurking in the TPP.

As this suggests, those who were opposed to the TPP's investment chapter before it was made public are not likely to change their minds now that they have a final text. ${ }^{144}$ But what is that "reformed" mechanism that Johnson alludes to? The EU's recently tabled proposal for an international investment court in the ongoing TTIP negotiations (along with comparable provisions in the European Union-Vietnam FTA and CETA), constitutes the latest possible reform for those still searching for the gold standard. ${ }^{145}$

The European Union's proposed dispute settlement system for the investment chapter of the TTIP would adopt many of the reformist measures already contained in the TPP (such as full transparency, a process for early dismissal of unfounded claims, and binding party interpretations) but crucially, would also establish a new international court system consisting of a Tribunal of First Instance (composed of 15 appointed judges) capped by an Appellate Tribunal (of six judges). ${ }^{146}$ The 15 judges of the Tribunal of First Instance would be appointed jointly by the European Union and United States governments and be composed of five European Union nationals, five United States nationals, and five nationals of third countries. The Appellate Tribunal would be composed of two judges from the European Union and the United States respectively, along with an additional two from third countries. All 21 judges would be appointed for renewable six-year terms, be barred from taking on any work as legal counsel on any investment disputes, and would be subject to strict ethical rules to prevent conflicts of interest. ${ }^{147}$ They would be expected to be persons comparable to those suited to judicial offices with demonstrated expertise in public international law. ${ }^{148}$ Under the

144 For a survey of evidence indicating that ten years after it was concluded, those who were for and against NAFTA's Investment Chapter appear not to have changed their minds about the wisdom of that treaty, see José E Alvarez "The NAFTA's Investment Chapter and Mexico" in Rudolf Dolzer, Matthias Herdegen and Bernhard Vogel (eds) Foreign Investment: Its Significance in Relation to the Fight Against Poverty, Economic Growth and Legal Culture (Konrad Adenauer Stiftung, Berlin, 2006) 241.

145 European Commission "EU-Vietnam Free Trade Agreement: Agreed text as of January 2016" European Commission: Trade <www.trade.ec.europa.eu>; and CETA, above n 76.

146 European Commission "Transatlantic Trade and Investment Partnership Trade in Services, Investment and E-Commerce: Chapter 2 - Investment (draft text)", arts 18 (transparency), 16-17 (preliminary objections), 13(5) (binding Committee interpretations) and 9-10 (establishing a Tribunal of First Instance and an Appeal Tribunal); and Draft TTIP text, above n 41.

147 Articles 9-11.

148 Articles 9(4) and 10(7). 
envisioned system, the disputing parties would not choose their judges; their claims would be adjudicated by groups of three judges (one each from the European Union, the United States, and from third countries) appointed, on a rotational basis, by the Presidents of the Tribunal of First Instance and the Appeal Tribunal respectively. ${ }^{149}$

The European Union proposal has been embraced by a number of scholars, including Robert Howse and Joost Pauwelyn. ${ }^{150}$ To proponents, replacing ISDS with an international investment court presents a commendable compromise between those who want no supranational review of host states that are charged with violating investors' rights and those who continue to embrace ISDS despite the sovereign backlash it has generated. ISDS, they claim, emerged largely by accident. It was the product of path dependency by those who were only familiar with arbitration as a method for settling inter-state disputes. If a system for adjudicating investment disputes had been designed today, it would have likely been inspired by today's "models of functioning transnational or international tribunals" instead. ${ }^{151}$

The European Union proposal is clearly intended to correct the perceived rule of law flaws of ISDS. It responds to the fundamental lack of trust with respect to the relatively small pool of party appointed investor-state arbitrators, many of whom litigate investment claims themselves, on the side of the state or investor, when they are not asked to preside over them. ${ }^{152}$ Proponents of the investment court see it as resolving adverse perceptions of arbitrator conflicts of interest while ensuring that investment adjudicators do not think of themselves as partisan representatives for the party that appointed them to the dispute. Establishing a formal court will, it is said, enable and encourage the genuine reason-giving and coherent case law that the rule of law demands and that investors and states both expect, given the need for clarity and certainty with respect to the applicable rules. ${ }^{153}$ The Appellate Tribunal in particular is seen as ensuring greater coherency in investment law, while also providing, unlike the limited ICSID annulment process, the possibility for correcting erroneous interpretations of law or egregious errors in fact-finding. The European

149 Articles 9(6)-(7) and 10(8)-(9).

150 Robert Howse Courting the Critics of Investor-State Dispute Settlement: the EU proposal for a judicial system for investment disputes (2015) (unpublished manuscript; on file with author); and Joost Pauwelyn "Why the US Should Support the EU Proposal for an 'Investment Court System"' (16 November 2015) LinkedIn <www.linkedin.com>.

151 Howse above n 150, at 7. See also Pauwelyn, above n 150, suggesting that the European Union proposal resembles the WTO's dispute settlement system, including its Appellate Body.

152 For a critique of party-appointed investor-state arbitrators, see for example Hans Smit "The Pernicious Institution of the Party-Appointed Arbitrator" in Karl P Sauvant and Jennifer Reimer (eds) FDI Perspectives: Issues in International Investment (2nd ed, Vale Columbia Center on Sustainable Development, New York, 2012) 187.

153 Compare Kingsbury and Schill, above n 52, urging greater attention to reason-giving within ISDS. 
Union proposal is also praised for ensuring that those who adjudicate these public disputes have the needed expertise in public international law. Proponents also contend that since the European Union proposal imposes strict time limits on the processing of claims as well on limits on the ensuing costs, there would be substantial efficiency benefits - at least as compared to ISDS where the average award now takes 3 and a half years and $\$ 8$ million to resolve. ${ }^{154}$ Finally, proponents of the European Union international investment court argue that it would replicate, for investment disputes, the WTO's successful dispute settlement scheme, which has brought rule of law without comparable sovereign backlash. ${ }^{155}$

Whether the European Union proposal for an international investment court and comparable provisions now appearing elsewhere presents the future of the investment regime - whether it is the new gold standard for those looking for a form of supranational investment regulation that does not generate sovereign backlash - remains to be seen. While the proposal for an international investment court may indeed correct many (if not all) ${ }^{156}$ of the perceived rule of law flaws that now trouble critics of ISDS, it does not eliminate the fundamental risk that now drives critics of the investment regime: namely the risk that sovereign decisions in the public interest will be secondguessed and chilled by the bringing of investor claims. Even if the envisioned investment court should come into being, ${ }^{157}$ there is nothing in the establishment of a permanent court, with or without an appellate body, that ensures that it will produce the types of sovereign-sensitive decisions that ISDS critics like Lise Johnson desire. The fact that under the European Union proposal two groups of judges will be in charge of interpreting the law does not mean that they will produce better

154 Howse, above n 150, at 12-14.

155 Pauwelyn, above n 150. See generally Joost Pauwelyn "The Rule of Law Without the Rule of Lawyers? Why Investment Arbitrators are from Mars, Trade Panelists are from Venus" (2015) 109 AJIL 761.

156 Notably, the European Union proposal does not cure one ISDS flaw: the complaint that the fellow adjudicators are expected to decide on challenges to arbitrators: see Draft TTIP Text, above n 41, art 11(3) anticipating that the President of the Tribunal or of the Appeal Tribunal respectively will decide on challenges to judges. Interestingly, CETA's comparable provision anticipates that such challenges will be decided by the President of the International Court of Justice: see CETA, above n 76, at 8.30 (2)-(3). The European Union proposal also adds a rule of law problem of its own. It anticipates that the proposed investment court's awards will be enforced only as between the parties to the TTIP: see CETA, above n 76, art. 30. ICSID awards are, of course, enforceable as among all ICSID parties.

157 Whether this occurs is not simply a matter of whether the EU's proposal is accepted by the United States and the TTIP is successfully concluded. It is not entirely clear whether the European Court of Justice will accept the existence of a "rival" body capable of interpreting European Union and international law: see Stephan Schill "The Proposed TTIP Tribunal and the Court of Justice: What Limits to Investor-State Dispute Settlement under EU Constitutional Law?" (29 September 2015) Verfassungblog <www.verfassungsblog.de> . 
- or more sovereign sensitive - treaty interpretations. As a noted United States Supreme Court justice once remarked, appellate review does not ensure correctness; it only ensures finality. ${ }^{158}$

Even if the European Union proposal will generate the appointment of judges with the kind of public international law expertise now associated with judges on the ICJ and the European Court of Human Rights, will those judges, faced with interpreting an investment protection treaty, be more likely to defer to sovereigns than today's ad hoc arbitrators? There is room for doubt on that score. The semi-permanent judges on an investment court, and especially those on the proposed Appeals Court, may be more, not less, empowered than an arbitrator appointed to a single case. Neither their status as semi-permanent judges of a formal court ${ }^{159}$ nor their envisioned expertise in public international law is necessarily likely to make them more deferential to states. Former ICJ judge Bruno Simma, a renowned expert on both public international law and human rights, was, after all, one of the two arbitrators writing the controversial (and singularly not deferential) majority opinion in the Bilcon case discussed above. Those who expect the envisioned international investment court to be more sympathetic to respondent states sued by investors may well be disappointed.

We should be mindful that investment and human rights treaties share some commonalities. Both are designed to protect the rights to property, non-discrimination and fair process from state abuse. Neither the European Court of Human Rights nor the Inter-American Court of Human Rights have been reticent about intruding into states' regulatory discretion. Both have seen their role as enforcers against the abuse of state power. Both of those permanent courts of public international law specialists have been criticised for not being sufficiently sensitive to the regulatory or security needs of states; both have generated their own measure of sovereign backlash.

On the other hand, to the extent advocates for the new investment court predict that its judges will come to resemble those now serving on WTO panels and its Appellate Body, there is room to doubt whether that possibility will generate the level of legitimacy desired and emulate the relative success of the WTO dispute settlement system as Pauwelyn suggests. As Pauwelyn has demonstrated, those who now serve as WTO adjudicators tend to come disproportionately from WTO governments, including trade ministries. ${ }^{160}$ It seems appropriate to turn to government functionaries - often former trade officials - to resolve trade disputes that trade ministers bring against one another. But investor-state claims are not between governments. The networks of international investor protection treaties have generated expectations that they are intended to

158 "We are not final because we are infallible, but we are infallible because we are final": Brown v Allen 344 US 443, (1953) at 540 per Jackson J.

159 The "semi-permanent" status of the proposed international investment court of the TTIP is suggested by the fact that its envisioned judges are not engaged as such permanently but only receive a monthly retainer fee to ensure their availability as disputes and appeals arise; in addition, certain administrative and legal secretariat services are outsourced to ICSID: see Draft TTIP Text, above n 41, arts 9-10.

160 Pauwelyn, above n 150. 
protect private third party beneficiaries and not only states' regulatory prerogatives. ${ }^{161}$ Whether government functionaries will satisfy these rule of law expectations and credibly preside over disputes between private investors and governments remains an open question.

The turn to ad hoc arbitration to revolve investor-state disputes may not have been entirely a historical accident or the unintended product of path dependency in favour of arbitration as has been suggested. ISDS itself is a compromise. Enabling both investors and respondent states to appoint their own respective arbitrators strikes a balance between likely biases on either side. It also enables private parties to feel a certain degree of party ownership and control over an adjudicative process that would otherwise be totally within the control of the states that they are suing. ${ }^{162}$ Of course, even if only an irrational default penchant for arbitration explains the rise and continued reliance on investor-state arbitration, it remains unclear whether those who have long been accustomed to exercising discretion on all the matters governing their dispute - from the appointment of arbitrators to the selection of arbitral rules and institutions - are ready to give all of that up for the untested merits of a single international investment court whose judges, rules and procedures have all been fashioned by the prospective respondent states - and over which governments will continue to assert interpretative control through the issuance of binding interpretations. As the chequered history (and still underutilised jurisdiction) of the ICJ suggests, even permanent courts with considerable legitimacy need to attract (and retain) their litigants. The European Union's international investment court may be an impressive rule of law achievement on paper, but one that, should it fail to secure the confidence of investors or states or both, may be left high and dry as its prospective litigants contract around it.

Some might question whether, for other reasons, the European Union's proposed investment court is a realistic gold standard. While that court may be popular with some scholars, the jury is out on whether it will be popular with governments outside Europe. Realists might point out that that the United States government (and most of Asia's governments) do not $d o$ international courts. While the recent FTA between the European Union and Vietnam suggests that some Asian states may yet change their minds on that score, ${ }^{163}$ the United States (and its Congress) is not likely to acquiesce in the European Union's proposal for an international investment court in the TTIP and some suspect that the European Union knows this all too well and is making the proposal for domestic consumption - to show those clamouring for a formal court that it tried and failed. Despite the displacement of ISDS in the European Union-Vietnam and CETA agreements, the prospect that

161 Compare Jeremy Waldron "Are Sovereigns Entitled to the Benefits of the International Rule of Law?" (2011) 22 EJIL 315 (questioning whether the international rule of law requires protecting the rights of sovereigns as sovereigns).

162 See generally Sophie Nappert "Escaping from Freedom? The Dilemma of an Improved ISDS Mechanism" (EFILA Annual Lecture, London, 26 November 2015).

163 "EU-Vietnam Free Trade Agreement", above n 145. 
the TPP will be re-opened to replace ISDS with an international investment court seems unlikely unless the United States changes its posture in favour of ISDS. ${ }^{164}$ Such a change would also require quite a change in the attitudes of many of the other TPP parties. There is no Asian court of human rights, after all, and it seems odd that the first such international court in the region would be one designed to protect only those persons with capital, namely investors. ${ }^{165}$

\section{CONCLUSION}

Those looking for the motivations of New Zealand's government when it entered into the TPP negotiations need look no further than the words of Alfred Lord Tennyson emblazoned on a wall in the international terminal of Auckland's airport: ${ }^{166}$

For I dipt into the future, far as human eye could see, Saw the vision of the world, and all the wonder that would be; Saw the heavens fill with commerce, argosies of magic sails, Pilots of the purple twilight dropping down with costly bales ...

At the risk of over simplification, New Zealand's current officials saw the investment chapter as the necessary price to be paid for the treaty's proffered gateway for new markets for New Zealand exports. Their vision of "heavens filled with commerce" led to the government's (perhaps reluctant) embrace of the TPP's investment chapter and ISDS.

The TPP's investment chapter pursues a reform path within the existing international investment regime that many other states, including the United States, support. Benvenisti and Kelsey emphasise that it is a path forged by the exercise of asymmetrical power among nations in which, as Kelsey states, "the world's declining but still powerful superpowers are trying to consolidate new global rules that entrench and advance their economic interests". ${ }^{167}$ But the fact that mega-regionals like the TPP may advance the economic and security interests of hegemons does not mean that, on balance, they may not also advance the interests of even small states like New Zealand. Most treaties - and indeed perhaps most of customary international law - have been the product of exercises of asymmetric power games. Unless we presume that the underlying games being played

164 Under the TPP's current provisions, it is more likely that its provisions for dispute settlement could be modified only by adding an appellate mechanism: see TPP, above $\mathrm{n} 3$, art 9.23.11 providing that "[i]n the event that an appellate mechanism for reviewing awards rendered by investor-State dispute settlement tribunals is developed in the future under other institutional arrangements, the Parties shall consider whether awards rendered under Article 9.29 (Awards) should be subject to that appellate mechanism".

165 Nor is the rather cynical Pauwelyn idea - that the European Union should just call for the establishment of WTO-like "panels" and an "appellate body" filled with "panelists" and not "judges" - likely to fool anyone who is adverse to permanent bodies of empowered individuals over the state even if appointed by the state: see Pauwelyn, above n 150.

166 Lord Alfred Tennyson Locksley Hall (1842).

167 Kelsey, above n 37. 
are zero-sum, this alone may not tell us that agreeing to the rules such negotiations produce are unwise for weaker negotiating parties. The TPP is made up of package deals of no less consequence than in the Law of the Sea Convention or on-going efforts to control climate change. It incorporates trade-offs between regulatory discretion and the benefits anticipated for trade in goods and global value chains. These trade-offs merit sober reflection.

Those examining whether the trade-offs embedded in the current text of the TPP's investment chapter are, on balance, of net benefit to New Zealand need to take into account likely alternatives. One alternative is suggested by those that seek to exit the investment regime (like Ecuador). That path is marked by a purported search for renewed forms of regional autonomy, self-determination, and more egalitarian forms of economic exchange. That path is less predictable in terms of longterm political, economic and security benefits, has uncertain support even from presumptive allies like Cuba, and may generate, in the worst case scenario, renewed turns to unilateral forms of selfhelp common to the pre-BIT world - or other, less lawyerly, ways to resolve investment disputes. A third, more radical reformist path is suggested by the European Union's proposed international investment court. This vision is built on a very European craving for international courts and a particular progress narrative for how best to generate and sustain the global rule of law.

We should not mistake these three possible routes to achieving the gold standard for the "end of history". ${ }^{168}$ Further pragmatic compromises among the three alternatives above are not only possible but likely. These may include, for example, continued reliance on ISDS, but the incorporation of an appellate mechanism. ${ }^{169}$ Even in the face of the competing European Union and United States visions for the future of the investment regime, countries like Brazil (that have remained outside ISDS) are attempting to carve out other alternatives, including a return to state-tostate arbitration. ${ }^{170}$ Only those whose imaginations are limited to trans-Atlantic developments are likely to suggest that the only choices are either the United States' - marked by the TPP - or the European Union's - and that any other possibilities are but futile efforts to find the Holy Grail.

168 See generally Francis Fukuyama The End of History and the Last Man (Free Press, New York, 1992).

169 See for example Stephan Schill "Editorial: US Versus EU Leadership in Global Investment Governance" (2016) 17 Journal of World Investment \& Trade 1 at 2. For other possibilities see for example United Nations Conference on Trade and Development World Investment Report 2015: Reforming International Investment Governance (United Nations, Geneva, 2015) at ch IV: Reforming the International Investment Regime: An Action Menu.

170 Joaquim de Paiva Muniz and Luis Peretti "Brazil Signs New Bilateral Investment Treaties with Mozambique and Angola: New Approach to BITs or "Toothless Lions'?" (17 April 2015) Global Arbitration News <www.globalarbitrationnews.com>. 


\section{ANNEX}

\section{United States-Argentina BIT (based on the United States Model BIT of 1987):}

Investment shall at all times be accorded fair and equitable treatment, shall enjoy full protection and security and shall in no case be accorded treatment less than that required by international law. Neither Party shall in any way impair by arbitrary and discriminatory measures the management, operation, maintenance, use, enjoyment, acquisition, expansion, or disposal of investments . . Each party shall observe any obligation it may have entered into with regard to investments.

\section{Argentina-Australia BIT (1995):}

Each Contracting Party shall at all times ensure fair and equitable treatment to investments.

\section{NAFTA (1994), Article 1105 (1):}

Each Party shall accord to investments of investors of another Party in accordance with international law, including fair and equitable treatment and full protection and security.

\section{NAFTA, The 31 July 2001 Free Trade Commission Interpretation:}

(1) Article 1105 (1) prescribes the customary international law minimum standard of treatment of aliens as the minimum standard of treatment to be afforded to investment of investors of another Party.

(2) The concepts of 'fair and equitable treatment' and 'full protection and security' do not require treatment in addition to or beyond that which is required by the customary international law minimum standard of treatment of aliens.

(3) A determination that there has been a breach of another provision of the NAFTA, or of a separate international agreement, does not establish that there has been a breach of Article 1105(1).

\section{United States 2004 Model BIT:}

Article 5: Minimum Standard of Treatment ${ }^{171}$

(1) Each Party shall accord to covered investments treatment in accordance with customary international law, including fair and equitable treatment and full protection and security

(2) For greater certainty, paragraph 1 prescribes the customary international law minimum standard of treatment of aliens as the minimum standard to be afforded to covered investments. The concepts of "fair and equitable treatment" and "full protection and 
security" do not require treatment in addition to or beyond that which is required by that standard, and do not create additional substantive rights. The obligation in paragraph 1 to provide:

(1) "fair and equitable treatment" includes the obligation not to deny justice in criminal, civil, or administrative adjudicatory proceedings in accordance with the principle of due process embodied in the principal legal systems of the world;

(2) "full protection and security" requires each party to provide the level of police protection required under customary international law.

(3) A determination that there has been a breach of another provision of this Treaty, or of a separate international agreement, does not establish that there has been a breach of this Article.

\section{ANNEX A}

\section{Customary International Law}

The parties confirm their shared understanding that "customary international law" generally and as specifically referenced in Article 5 [Minimum Standard of Treatment] and Annex B [Expropriation] results from a general and consistent practice of States that they follow from a sense of legal obligation. With regard to Article 5 [Minimum Standard of Treatment], the customary international law minimum standard of treatment of aliens refers to all customary international law principles that protect the economic rights and interests of aliens.

\section{Canada-European Union: Comprehensive economic and Trade Agreement (CETA) (2016)}

Chapter Eight: Investment

Section D: Investment Protection

Article 8.10: Treatment of Investors and of Covered Investments

(1) Each Party shall accord in its territory to covered investments of the other Party and to Investors with respect to their covered investments fair and equitable treatment and full protection and security in accordance with paragraphs 2 to 6 .

(2) A Party breaches the obligation of fair and equitable treatment referenced in paragraph 1 where a measure or series of measures constitutes:

(a) denial of justice in criminal, civil or administrative proceedings;

(b) fundamental breach of due process, including a fundamental breach of transparency, in judicial and administrative proceedings;

(c) manifest arbitrariness; 
(d) targeted discrimination on manifestly wrongful grounds, such as gender, race or religious belief;

(e) abusive treatment of investors, such as coercion, duress and harassment; or

(f) a breach of any further elements of the fair and equitable treatment obligation adopted by the Parties in accordance with paragraph 3 of this Article.

(3) The Parties shall regularly, or upon request of a Party, review the content of the obligation to provide fair and equitable treatment. The Committee on Services and Investment, established under Article 26.2.1(b) (Specialised committees), may develop recommendations in this regard and submit them to the CETA Joint Committee for decision.

(4) When applying the above fair and equitable treatment obligation, a tribunal may take into account whether a Party made a specific representation to an investor to induce a covered investment, that created a legitimate expectation, and upon which the investor relied in deciding to make or maintain the covered investment, but that the Party subsequently frustrated.

(5) For greater certainty, 'full protection and security' refers to the party's obligations relating to physical security of investors and covered investments.

(6) For greater certainty, a breach of another provision of this Agreement, or of a separate international Agreement, does not establish that there has been a breach of this Article.

(7) For greater certainty, the fact that a measure breaches domestic law does not, in and of itself, establish a breach of this Article. In order to ascertain whether the measure breaches this Article, a Tribunal must consider whether a party has acted inconsistently with the obligations in paragraph 1 .

\section{Trans-Pacific Partnership (2015)}

\section{Article 9.6: Minimum Standard of Treatment [15]}

(1) Each party shall accord to covered investments treatment in accordance with applicable customary international law principles, including fair and equitable treatment and full protection and security

(2) For greater certainty, paragraph 1 prescribes the customary international law minimum standard of treatment of aliens as the standard of treatment to be afforded to covered investments. The concepts of "fair and equitable treatment" and "full protection and security" do not require treatment in addition to or beyond that which is required by that standard, and do not create additional substantive rights. The obligations in paragraph 1 to provide: 
(a) "fair and equitable treatment" includes the obligation not to deny justice in criminal, civil or administrative adjudicatory proceedings in accordance with the principle of due process embodied in the principal legal systems of the world; and

(b) "full protection and security" requires each Party to provide the level of police protection required under customary international law.

(3) A determination that there has been a breach of another provision of this Agreement, or of a separate international agreement, does not establish that there has been a breach of this Article.

(4) For greater certainty, the mere fact that a Party takes or fails to take an action that may be inconsistent with an investor's expectations does not constitute a breach of this Article, even if there is loss or damage to the covered investment as a result.

[15] Article 9.6 (Minimum Standard of Treatment) shall be interpreted in accordance with Annex 9-A (Customary International Law)

\section{Annex 9-A Customary International Law}

The Parties confirm their shared understanding that "customary international law" generally and as specifically referenced in Article 9.6 (Minimum Standard of Treatment) results from a general and consistent practice of States that they follow from a sense of legal obligation. The customary international law minimum standard of treatment of aliens refers to all customary international law principles that protect the investments of aliens. 